Columbia International Publishing

American Journal of Oral Medicine

(2017) Vol. 3 No. 1 pp. 1-24

doi:10.7726/ajom.2017.1001

Research Article

\title{
Correlation between Loss of E-cadherin, Matrix- metalloproteinases and c-Jun expression in Oral Carcinogenesis
}

\author{
Bhairavi N. Vajaria ${ }^{1}$, Kinjal R. Patel ${ }^{1}$, Rasheedunnisa Begum ${ }^{2}$, Franky D. Shah ${ }^{1}$, Jayendra B. Patel ${ }^{1}$, \\ Geeta M. Joshi ${ }^{3}$, and Prabhudas S. Patel ${ }^{*}$
}

Received: 03 October 2016; Returned for revision: 05 November 2016; Received in revised form: 28 November 2016; Accepted: 30 November 2016; Published online: 4 February 2017

(C) Columbia International Publishing 2017. Published at www.uscip.us

\begin{abstract}
Background: Earlier invitro studies have observed that loss of E-cadherin is responsible for progression and metastasis of cancer by upregulation of c-Jun protein. There being lack of simultaneous evaluation of matrix metalloproteinase (MMP) -2 and -9, E-cadherin and c-Jun mRNA and protein.
\end{abstract}

Objective: This study aimed to correlate the above-mentioned parameters to evaluate the pathway of oral carcinogenesis.

Methods: The study included 100 controls, 50 patients with oral precancerous conditions (OPC) and 100 oral cancer patients. MMPs were evaluated by gelatin zymography, ECAD and CJUN mRNA and protein expression by semi quantitative RT-PCR and western blot respectively.

Results: The levels of active and total MMP-2 and MMP-9 were significantly higher in patients with OPC and oral cancer patients as compared to controls. A significant increase in truncated E-cadherin and c-Jun protein was observed in malignant tissues as compared to adjacent normal tissues while CJUN mRNA levels were comparable. Higher values of c-Jun protein and MMPs, and lower values of ECAD mRNA were associated with reduced overall survival. A positive correlation was observed between truncated E-cadherin, MMPs and c-Jun protein.

Conclusions: MMPs modulate cell-cell adhesion by increasing truncation of E-cadherin resulting in loss of Ecadherin which is responsible for upregulation of c-Jun protein in oral cancer.

Keywords: E-cadherin; Matrix metalloproteinase; c-Jun; Oral cancer; Oral precancerous conditions

*Corresponding e-mail: prabhudas_p@hotmail.com

1 Biochemistry Research Division, The Gujarat Cancer \& Research Institute, Asarwa, Ahmedabad 380016 Gujarat, India.

2 Department of Biochemistry, The M. S. University of Baroda 390 002, Vadodara, Gujarat, India.

3 Deputy Director, The Gujarat Cancer \& Research Institute, Asarwa, Ahmedabad 380 016, Gujarat, India. 
Bhairavi N. Vajaria, Kinjal R. Patel, Rasheedunnisa Begum, Franky D. Shah, Jayendra B. Patel, Geeta M. Joshi, and Prabhudas S. Patel / American Journal of Oral medicine (2017) Vol. 3 No. 1 pp. 1-24

\section{Introduction}

According to Global Cancer Statistics, oral cancer is one of the major health burden with 3,00,373 new oral cancer cases and 1,45,353 deaths worldwide (Ferlay et al., 2012) and is sixth most common malignancies in Asia (Rao et al., 2013). The Indian subcontinent accounts for one-third of the world's oral cancer burden and late presentation many times with metastasis is common resulting into a strenuous problem (More et al., 2013; Khan et al., 2012).

E-cadherin, a key modulator in cell-cell adhesion has been known to play an important role in malignant transformation and in epithelial malignant transformation (EMT). E-cadherin loss has been observed in major metastasis (Kowalski et al., 2003). It has been reported that just as a critical EMT event in decreasing the E-cadherin expression, the re-expression of E-cadherin is proposed to be the important hallmark of mesenchymal epithelial transformation (MET). Re-expression of Ecadherin also included MET in pancreatic tumor cell line and resulted in increased mRNA and protein expression of $\alpha$ and $\beta$-catenin (Yao et al., 2011). Another plausible mechanism has been proposed to explain the changes in the cell phenotype, numerous signals in primary tumors actively promote the induction and continued expression of an EMT, whereas as tumor cells that leave the primary site may revert to the epithelial state due to the absence of EMT- inducing signals (Frisch et al., 1997).

Investigators have proposed that MET during the progress of invasive and metastatic carcinoma, epithelial cancer cells can invade the surrounding tissue and metastasize, via functional cooperation between mesenchymal and more differentiated epithelial cancer cells and then participate in the formation of metastasis that are histopathologically similar to primary tumors (Tsuji et al., 2009). At present the process of metastasis is still poorly understood.

Matrix metalloproteinases (MMPs) play important role in metastasis and invasion by proteolytic degradation of extracellular matrix (ECM), disruption of cell-cell and cell matrix adhesion, migration and angiogenesis (Gialeli et al., 2011; Roy et al., 2009). Initially, MMPs were thought to be important exclusively in invasion and metastasis, but recent studies have demonstrated that MMPs play a role in several steps during carcinogenesis (Yadav et al., 2014). Earlier reports have documented the loss of E-cadherin, a cell adhesion molecule in oral precancerous conditions (OPC) also (Shah et al., 2009). Further, MMPs are well-known modulators the cell-cell and cell-ECM interactions affecting both cell phenotype (epithelial mesenchymal transition) and increasing cell migration (Gialeli et al., 2011). Hence, understanding MMPs in oral precancerous conditions would help in monitoring early events in tumorigenesis. Earlier reports from our laboratory and others have indicated elevated tissues and plasma levels of MMP-2 and MMP-9 in oral cancer patients (Singh et al., 2011; Singh et al., 2010; Tao et al., 2014). Increase in the expression of MMP-2 from normal oral mucosa to dysplasia to oral cancer has been reported recently during oral carcinogenesis (Shrestha et al., 2014). Earlier immunohistochemical analysis has shown significant immunoreactivity of MMP-2 and MMP-9 in oral lichen planus (Al-Rawi et al., 2014). However, there are very few studies on MMPs in OPC documenting correlation of MMP-2 and MMP-9 with Ecadherin mRNA and protein simultaneously.

Recent evidence suggests that loss of E-cadherin mediated cell-cell adhesion is responsible for increase in proto-oncogene c-Jun, a key player in tumorigenesis (Knirsh et al., 2009). It has been 
Bhairavi N. Vajaria, Kinjal R. Patel, Rasheedunnisa Begum, Franky D. Shah, Jayendra B. Patel, Geeta M. Joshi, and Prabhudas S. Patel / American Journal of Oral medicine (2017) Vol. 3 No. 1 pp. 1-24

documented earlier that cytoskeleton dependent increase in c-Jun accumulation was not accompanied by an increase in CJUN mRNA but rather in the translatability of c-Jun transcript. Such a control was suggested to be due to internal ribosomal entry site (IRES) mediated translation (Polak et al., 2006).

MMPs are the enzymes which plays an important role in metastasis and invasion by proteolytic degradation of ECM, disruption of cell-cell and cell-matrix adhesion, migration and angiogenesis (Vihenen et al., 2002; Gialeli et al., 2011; Roy et al., 2009). These are released into the circulation and are found in body fluids. Hence MMPs were evaluated from plasma. Proteolytic degradation of E-cadherin is one of the mechanism by which E-cadherin mediated cell-cell adhesion can be ablated (Cavallaro et al., 2004). A soluble $80 \mathrm{kD}$ form of E-cadherin, have an active part in the invasive process during tumor progression (Navrocki-Raby et al., 2003). Moreover, earlier studies have demonstrated that post-translational cleavage of native Ecad results in $\mathrm{Mr} 97000$ fragment Ecad ${ }^{97}$. This is one of the mechanism by which E-cadherin function is abrogated. Hence in the present study, MMPs and E-cadherin were simultaneously analyzed.

To our knowledge, there are lack of invivo studies correlating simultaneously MMPs, protein and mRNA levels of E-cadherin and c-Jun. Hence the present study was undertaken for simultaneous evaluation of MMPs, mRNA and protein levels of E-cadherin and c-Jun in oral cancer. The evaluation of MMPs in patients with OPC would help in deciphering the role of MMPs during early neoplastic transformation.

\section{Methodology}

\subsection{Subjects}

The study was approved by Institutional Review Board of The Gujarat Cancer \& Research Institute, Ahmedabad, Gujarat, India. Due consent was obtained from all the subjects who participated in the study. The subjects included in the study consisted of 100 healthy individuals (controls) who had no major illness in the recent past, 50 patients with OPC and 100 histopathologically proven untreated oral cavity cancer patients. The subjects were enrolled from The Gujarat Cancer \& Research Institute, Ahmedabad. Out of 50 patients with OPC, 39 patients were with oral sub mucous fibrosis and 11 patients were with oral leukoplakia. Pathological tumor, node and metastasis (TNM) staging of malignant disease was performed as per American Joint Committee on Cancer (AJCC) norms (Greene et al., 2002). The clinico-pathological details of oral cancer patients are mentioned in Table 1. The oral cancer patients included in the study were followed for a period of 45 months and correlation of the molecular markers under the study with overall survival was analyzed.

\subsection{Sample collection}

Plasma was separated from the blood collected of 100 oral cancer patients, 50 patients with OPC and 100 healthy controls. Tissue samples from oral cancer patients (50 paired tissues) were collected on ice from operation theater immediately after surgical resection of the tumors. Adjacent normal tissue samples were selected from the tumor free margins at least $2-3 \mathrm{~cm}$ away from the tumor as defined by the pathologist. The tissue specimens were washed with ice-cold phosphate 
Bhairavi N. Vajaria, Kinjal R. Patel, Rasheedunnisa Begum, Franky D. Shah, Jayendra B. Patel, Geeta M. Joshi, and Prabhudas S. Patel / American Journal of Oral medicine (2017) Vol. 3 No. 1 pp. 1-24

buffer saline (PBS: $\mathrm{pH} 7.4$ ) and were stored at $-80^{\circ} \mathrm{C}$ until analyzed. For RNA analysis, RNA 'later' (Qiagen, Valencia, CA, USA) was added to the tissues and were stored at $-80^{\circ} \mathrm{C}$ until analyzed.

Table 1 Clinicopathological details of oral cancer patients from parameters analyzed

\begin{tabular}{|c|c|c|c|}
\hline \multirow[t]{2}{*}{ Clinical characteristics } & \multicolumn{3}{|c|}{ Oral cancer patients } \\
\hline & $\begin{array}{c}\text { MMPs } \\
(\mathrm{N}=100)\end{array}$ & $\begin{array}{l}\text { E-cadherin } \\
\text { c-Jun protein } \\
(\mathrm{N}=25)\end{array}$ & $\begin{array}{c}E C A D / \\
\text { CJUN mRNA } \\
(\mathrm{N}=50)\end{array}$ \\
\hline \multicolumn{4}{|l|}{ Histopathology } \\
\hline Squamous cell carcinoma & 97 & 25 & 48 \\
\hline Verrucous carcinoma & 03 & --- & 02 \\
\hline \multicolumn{4}{|l|}{ Disease site } \\
\hline Buccal mucosa & 45 & 06 & 21 \\
\hline Oral tongue & 21 & 05 & 09 \\
\hline Alveolus & 08 & 04 & 06 \\
\hline $\begin{array}{l}\text { Others (Lip, central arch, retro } \\
\text { molar trigone, gingivo-buccal } \\
\text { sulcus or mixed sites) }\end{array}$ & 26 & 10 & 14 \\
\hline \multicolumn{4}{|l|}{ Lymph node metastasis } \\
\hline No / Yes & $56 / 34$ & $19 / 05$ & $29 / 18$ \\
\hline Undefined & 10 & 01 & 03 \\
\hline \multicolumn{4}{|l|}{ Stage of disease } \\
\hline I / II & $16 / 16$ & $02 / 07$ & $3 / 14$ \\
\hline Early disease (I + II) & 32 & 09 & 17 \\
\hline III / IV & $8 / 34$ & $01 / 014$ & $6 / 25$ \\
\hline Advanced disease (III + IV) & 62 & 15 & 31 \\
\hline Undefined & 6 & 01 & 02 \\
\hline \multicolumn{4}{|l|}{ Tumor differentiation } \\
\hline Well & 33 & 09 & 17 \\
\hline Moderate & 57 & 14 & 28 \\
\hline Poor & 5 & 01 & 02 \\
\hline Undefined & 5 & 01 & 03 \\
\hline
\end{tabular}

\subsection{Total Proteins}

Total protein levels from plasma euglobulin fraction / tissue lysates were determined using the Folin Lowry's method (Lowry et al., 1951). The standard curve was prepared using bovine serum 
Bhairavi N. Vajaria, Kinjal R. Patel, Rasheedunnisa Begum, Franky D. Shah, Jayendra B. Patel, Geeta M. Joshi, and Prabhudas S. Patel / American Journal of Oral medicine (2017) Vol. 3 No. 1 pp. 1-24

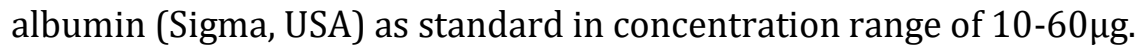

\subsection{Gelatin zymography}

Gelatin Zymography was performed from plasma euglobulin fraction. For euglobulin fraction, 0.1 $\mathrm{ml}$ of plasma was mixed with $0.9 \mathrm{ml}$ of DDW. To this $40 \mu \mathrm{l}$ of $1 \%$ Acetic acid was added and incubated at $0^{\circ} \mathrm{C}$ for 1 hour. Further the solution was centrifuged at $5000 \mathrm{rpm}$ for 10 minutes in cooling centrifuge. The supernatant was discarded. Further the pellet (euglobulin) was dissolved in $0.1 \mathrm{ml}$ phosphate buffer saline. Protein estimation of dissolved fraction was performed by FolinLowry's method. Equal amount i.e. $100 \mu$ g plasma euglobulin was mixed with sample buffer and loaded on loaded on $7.5 \%$ SDS-PAGE (containing $0.5 \mathrm{mg} / \mathrm{ml}$ gelatin) and gelatin zymography was performed by methodology as described by Lorenzo et al. (Lorenzo et al., 1992). These zymograms were quantitated using gel documentation system (Alpha Innotech, USA). The integrated density value (IDV) i.e. the sum of all the pixel values after background correction, was determined for each proteinase activity. The reproducibility of the samples was checked by running the samples in same gels as well as in different gels.

\subsection{Semi-quantitative RT-PCR}

RNA was isolated from all the tissue (paired adjacent normal and malignant, $n=50$ ) samples collected from oral cancer patients using RNA isolation kit (Qiagen, Valencia, CA, USA) and stored at $-80^{\circ} \mathrm{C}$. Semi-quantitative RT-PCR from transcripts was carried out using specific primer sequences ECAD (Zhang et al., 2007), CJUN (Chatzistamou et al., 2000), BACTIN:F5'GGTCACCCACACTGTGCCCAT-3';R5'-GGATGCCACAGGACTCCATGC-3'. $\beta A C T I N$ was used as internal control in all the reactions and RT-PCR was carried out using one-step RT-PCR kit (Qiagen, Valencia, CA, USA). The reaction products were electrophoresed on $1.5 \%$ agarose gels containing ethidium bromide and gels were analyzed densitometrically using gel documentation system (Alpha Innotech, USA). The relative mRNA expression was expressed by normalizing to BACTIN.

\subsection{Western blot}

Tissue lysate was prepared by lysis of $50 \mathrm{mg}$ of tissue with lysis buffer. After centrifugation, the lysate supernatant was taken in another fresh microcentrifuge tube and its total protein content was estimated (Lowry et al., 1951). The running gel of $10 \%$ and $12 \%$ were prepared for E-cadherin and c-Jun protein, respectively. The tissue lysates equivalent to $100 \mu \mathrm{g}$ protein was loaded. The proteins were separated on SDS-PAGE under denaturing and reducing conditions at constant voltage. After electro-transfer, the membrane was incubated in $5 \% \mathrm{w} / \mathrm{v}$ blocking reagent for $1 \mathrm{~h}$ at room temperature. After washing, the membrane was incubated overnight with primary antibody i.e. anti E-cadherin antibody i.e. mouse monoclonal HECD1 antibody (Calbiochem, USA), anti-c-Jun G-4 mouse monoclonal antibody (Santacruz Biotech) and $\beta$-Actin antibody (Santacruz Biotech, USA) with gentle shaking. The membrane was rinsed thrice with TBS-T (1x15 min and 2x5 min) and then incubated with appropriate HRP conjugated anti-mouse secondary antibody (1:1000 dilution in TBS-T) for 2 hrs with gentle shaking. The detection was performed by autoradiography (chemiluminescence method) using ECL western blotting detection kit (GE Health care) by capturing luminescensce on light sensitive hyperfilm. The densitometric analysis of protein band 
Bhairavi N. Vajaria, Kinjal R. Patel, Rasheedunnisa Begum, Franky D. Shah, Jayendra B. Patel, Geeta M. Joshi, and Prabhudas S. Patel / American Journal of Oral medicine (2017) Vol. 3 No. 1 pp. 1-24

was performed using densitometer (Alpha Innotech Inc) and was expressed as IDV i.e. the sum of all the pixel values after background correction.

\subsection{Statistical analysis}

Statistical analysis of the data was performed using statistical package for social science (SPSS) software version 17.0. Student's paired ' $t$ ' test was used to compare the mRNA and protein levels of E-cadherin and c-Jun between adjacent normal and malignant tissues of the oral cancer patients. Student's independent ' $t$ ' test was performed to assess the levels of significance of markers with various clinico-pathological parameters. Pearson's correlation analysis was performed to assess the correlation between various forms of plasma MMPs, mRNA and protein expression of E-cadherin and c-Jun. Receiver's operating characteristic's (ROC) curve analysis was performed to obtain optimal cut-off point for survival analysis. Kaplan-Meier survival analysis was used to analyze correlation of the markers with overall survival and significance of differences in survival rates was analyzed by Log rank test. Multivariate analysis was performed to correlate the markers simultaneously with various clinico-pathological parameters. The values were expressed as the Mean \pm Standard Error of Mean (SEM). ' $p$ ' value less than 0.05 was considered to be statistically significant.

\section{Results}

3.1 Comparison of plasma pro, active and total MMP-2 and MMP-9 in controls, patients with OPC and oral cancer patients

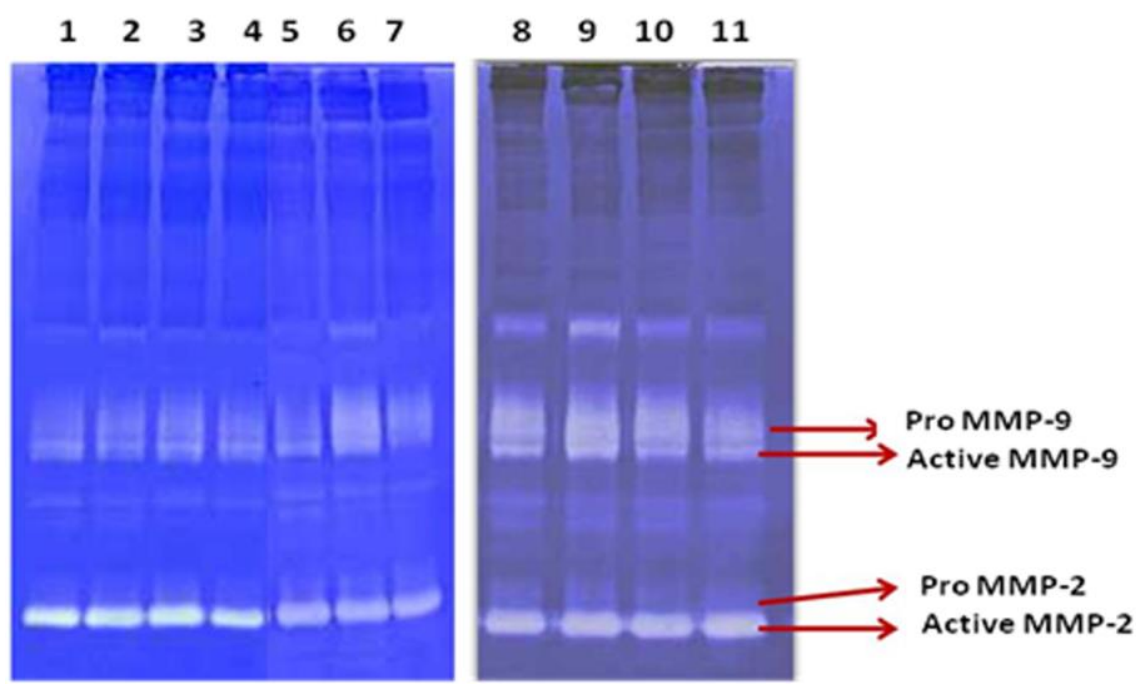

Fig. 1A Representative pattern of gelatin zymography from plasma. Lane 1, 2, 3 and 4 depicts controls; lane 5, 6 and 7 represents patients with OPC; lane 8, 9, 10 and 11 represents oral cancer patients. OPC: Oral precancerous conditions 
Bhairavi N. Vajaria, Kinjal R. Patel, Rasheedunnisa Begum, Franky D. Shah, Jayendra B. Patel, Geeta M. Joshi, and Prabhudas S. Patel / American Journal of Oral medicine (2017) Vol. 3 No. 1 pp. 1-24

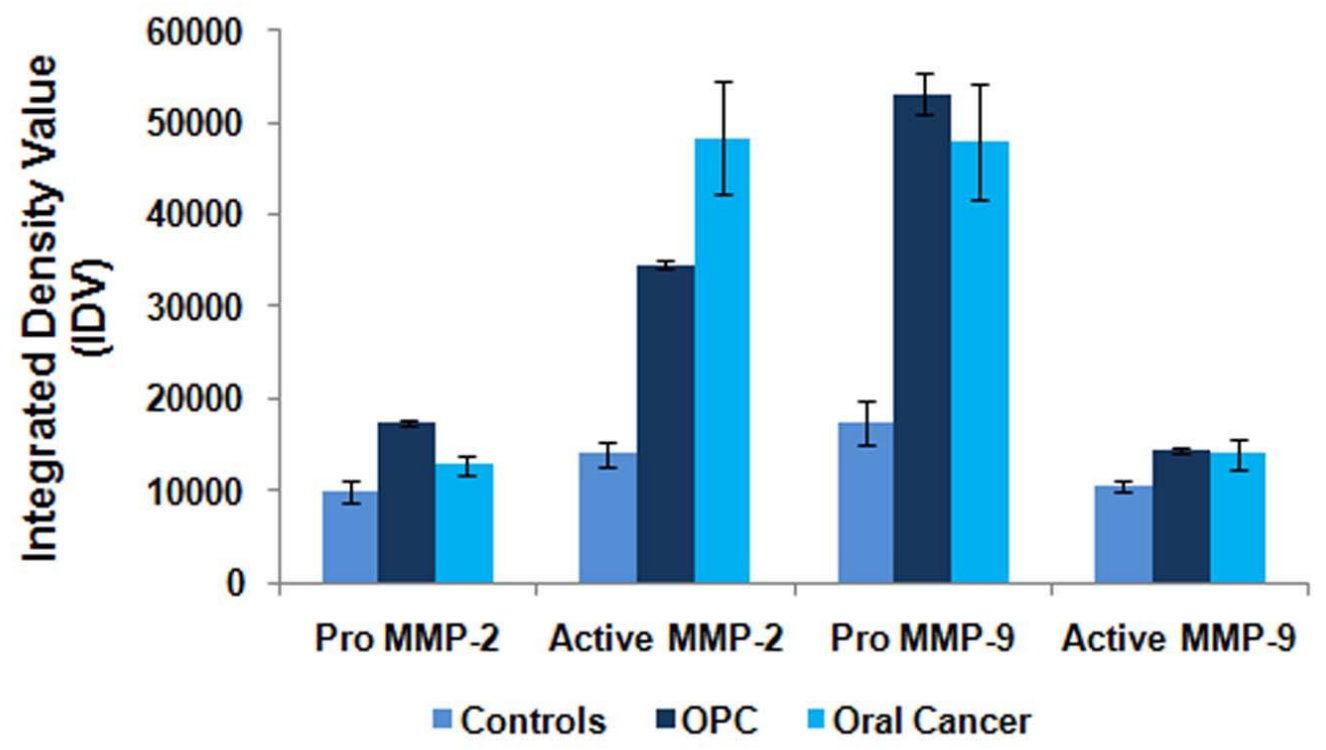

Fig. 1B Comparison of plasma pro MMP-2, active MMP-2, pro MMP-9, active MMP-9 in controls, patients with OPC and oral cancer patients. Levels expressed as Integrated Density Value (IDV).

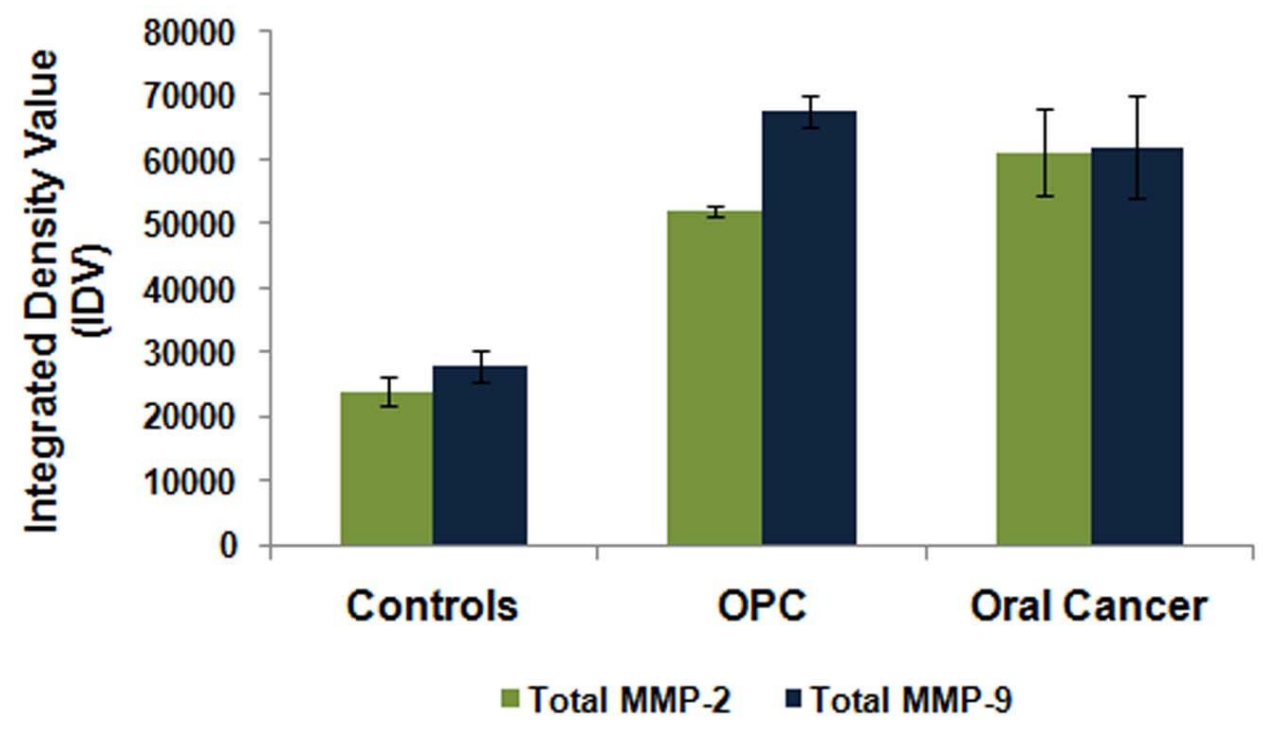

Fig. 1C Comparison of total MMP-2 and total MMP-9 in controls, patients with OPC and oral cancer patients. Levels expressed as Integrated Density Value (IDV).

Plasma MMPs were estimated from 100 controls, 50 patients with OPC and 100 oral cancer patients. Fig. 1A is the representative pattern of gelatin zymogram in controls, patients with OPC 
Bhairavi N. Vajaria, Kinjal R. Patel, Rasheedunnisa Begum, Franky D. Shah, Jayendra B. Patel, Geeta M. Joshi, and Prabhudas S. Patel / American Journal of Oral medicine (2017) Vol. 3 No. 1 pp. 1-24

and oral cancer patients. As depicted in Fig. 1B and 1C, the levels of pro, active and total MMP-2 and MMP-9 were significantly higher in patients with OPC $(\mathrm{p}<0.0001)$ as compared to the controls. Active MMP-2, pro and active MMP-9, total MMP-2 and MMP-9 were significantly higher in oral cancer patients ( $\mathrm{p}<0.0001, \mathrm{p}<0.0001, \mathrm{p}=0.051, \mathrm{p}<0.0001$, respectively) as compared to the controls (Table 2) by student's independent t' test. Similarly, active MMP-2 was observed to be significantly higher in oral cancer patients as compared to patients with OPC $(\mathrm{p}=0.025)$.

Table 2 Significance of comparison of pro, active and total MMP-2 and MMP-9 between controls, patients with OPC and oral cancer patients

\begin{tabular}{|l|c|c|c|c|c|c|}
\hline \multicolumn{1}{|c|}{$\begin{array}{c}\text { Groups } \\
\text { compared }\end{array}$} & Pro MMP-2 & $\begin{array}{c}\text { Active } \\
\text { MMP-2 }\end{array}$ & $\begin{array}{c}\text { Pro MMP- } \\
\mathbf{9}\end{array}$ & $\begin{array}{c}\text { Active } \\
\text { MMP-9 }\end{array}$ & $\begin{array}{c}\text { Total } \\
\text { MMP-2 }\end{array}$ & $\begin{array}{c}\text { Total } \\
\text { MMP-9 }\end{array}$ \\
\hline $\begin{array}{l}\text { Controls Vs. } \\
\text { patients with OPC }\end{array}$ & $\mathrm{p}<0.0001$ & $\mathrm{p}<0.0001$ & $\mathrm{p}<0.0001$ & $\mathrm{p}<0.0001$ & $\mathrm{p}<0.0001$ & $\mathrm{p}<0.0001$ \\
\hline $\begin{array}{l}\text { Controls vs. Oral } \\
\text { cancer }\end{array}$ & $\mathrm{p}=0.071$ & $\mathrm{p}<0.0001$ & $\mathrm{p}<0.0001$ & $\mathrm{p}=0.051$ & $\mathrm{p}<0.0001$ & $\mathrm{p}<0.0001$ \\
\hline $\begin{array}{l}\text { Patients with OPC } \\
\text { vs. Oral cancer }\end{array}$ & $\mathrm{p}<0.0001$ & $\mathrm{p}=0.025$ & $\mathrm{p}=0.427$ & $\mathrm{p}=0.868$ & $\mathrm{p}=0.341$ & $\mathrm{p}=0.496$ \\
\hline
\end{tabular}

\subsection{ECAD and CJUN mRNA expression in malignant and adjacent normal tissues}

ECAD and CJUN mRNA expression was estimated from 50 paired tissues by semiquantitative RTPCR using ECAD and CJUN specific primers and levels were normalized to $\beta A C T I N$ expression. Fig. $2 \mathrm{~A}$ shows the band of $420 \mathrm{bp}$ i.e. of $E C A D$ mRNA expression. The analysis by paired ' $t$ ' test revealed that ECAD mRNA levels were comparable between malignant and adjacent normal tissues (Fig. 2B). Fig. $3 \mathrm{~A}$ is the representative pattern of $C J U N$ mRNA expression which shows the band of $404 \mathrm{bp}$ of CJUN. Fig. 3B depicts that the levels of CJUN mRNA were comparable between paired malignant and adjacent normal tissues by paired ' $t$ ' test. 
Bhairavi N. Vajaria, Kinjal R. Patel, Rasheedunnisa Begum, Franky D. Shah, Jayendra B. Patel, Geeta M. Joshi, and Prabhudas S. Patel / American Journal of Oral medicine (2017) Vol. 3 No. 1 pp. 1-24

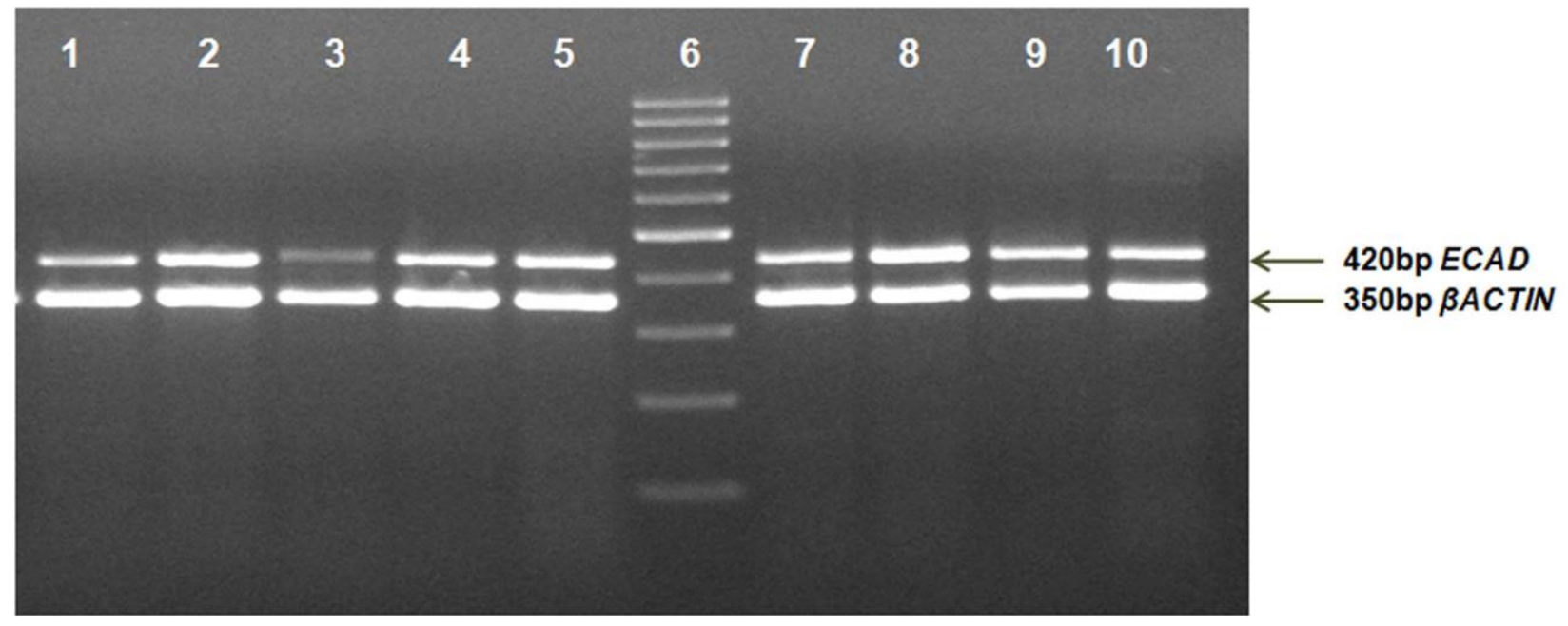

Fig. 2A Representative pattern of ECAD mRNA expression in paired malignant and adjacent normal tissues. Lanes 1, 3, 5, 8, 10 shows the amplicon pairs of ECAD (420bp) and $\beta A C T I N$ (350bp) from malignant tissues. Lanes $2,4,7$, and 9 shows the expression from adjacent normal tissues. Lane 6 represents the DNA ladder (100-1000bp).

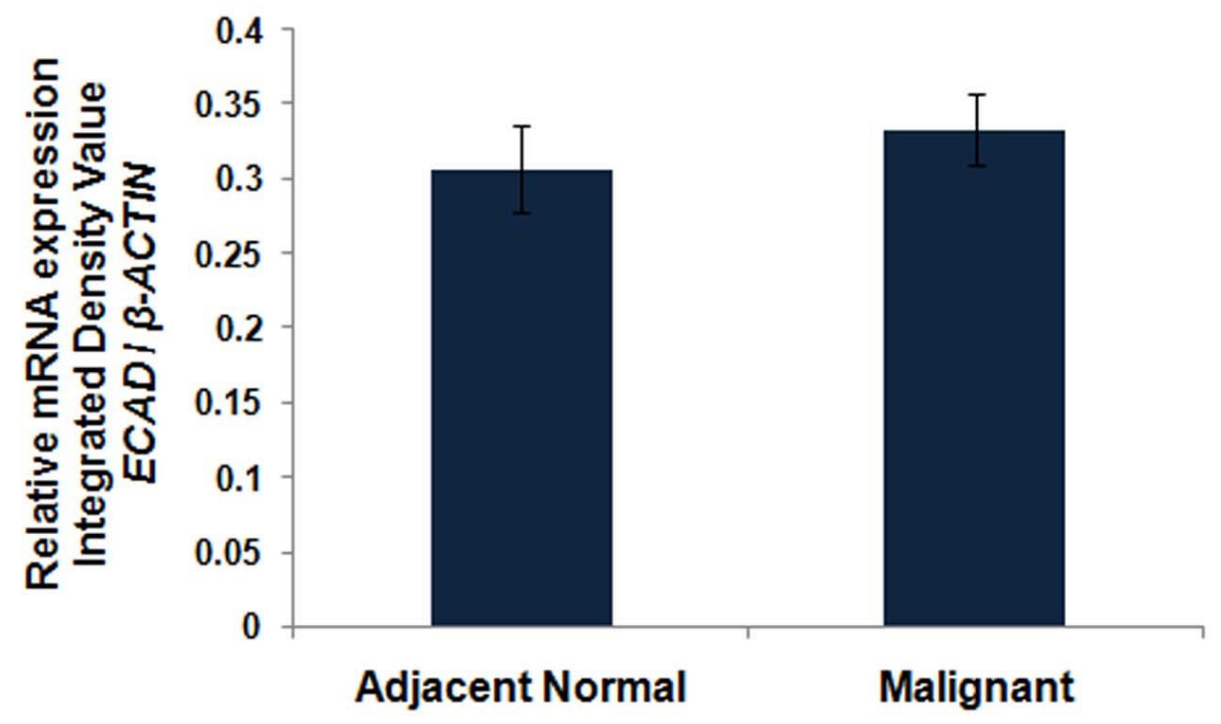

Fig. 2B Graphical representation of ECAD mRNA expression in paired adjacent normal and malignant tissues. The levels are expressed as IDV of ECAD/ $\beta A C T I N$. 
Bhairavi N. Vajaria, Kinjal R. Patel, Rasheedunnisa Begum, Franky D. Shah, Jayendra B. Patel, Geeta M. Joshi, and Prabhudas S. Patel / American Journal of Oral medicine (2017) Vol. 3 No. 1 pp. 1-24

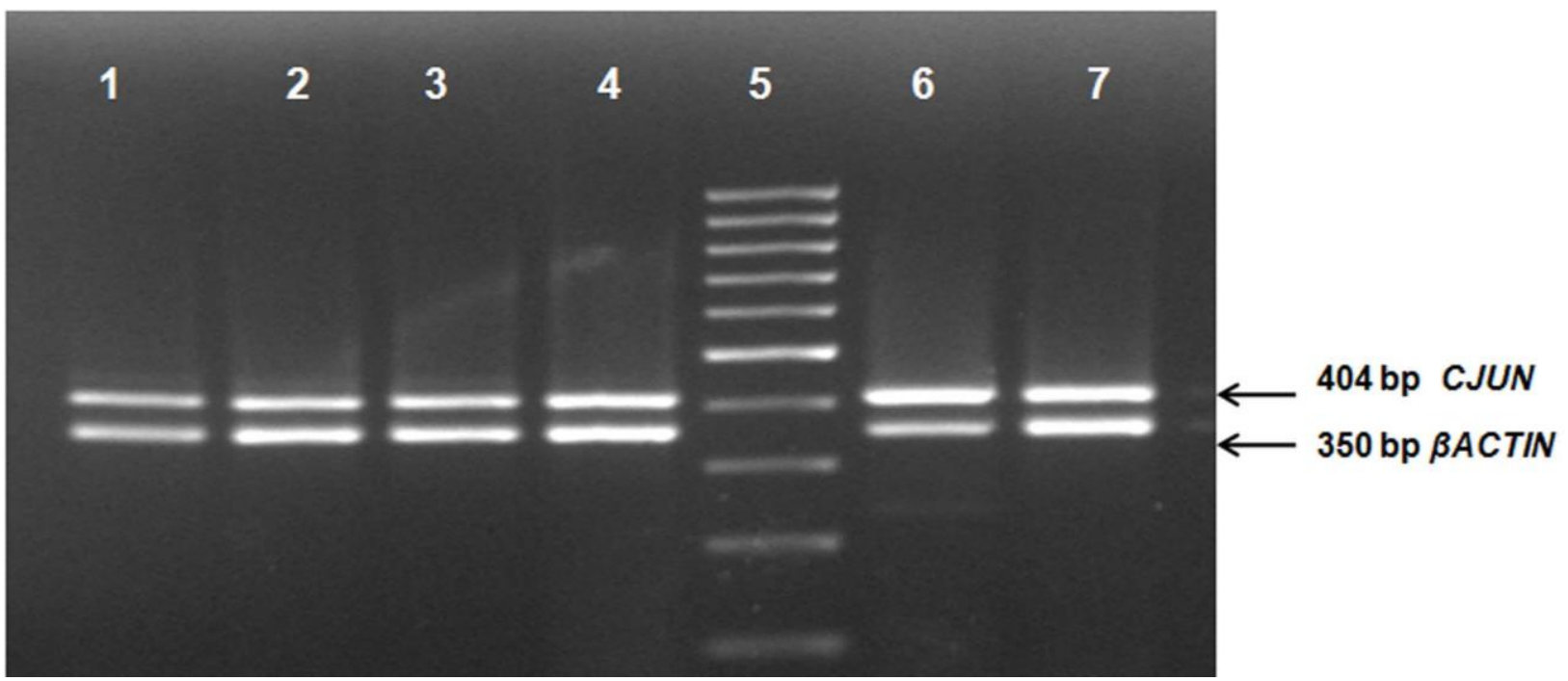

Fig. 3A Representative pattern of $C J U N$ mRNA expression in paired malignant and adjacent normal tissues. Lanes 1, 3, 6 shows the amplicon pairs of CJUN (404bp) and BACTIN (350bp) from adjacent normal tissues. Lanes 2, 4, 7 shows the expression from malignant tissues. Lane 5 represents the DNA ladder (100-1000bp).

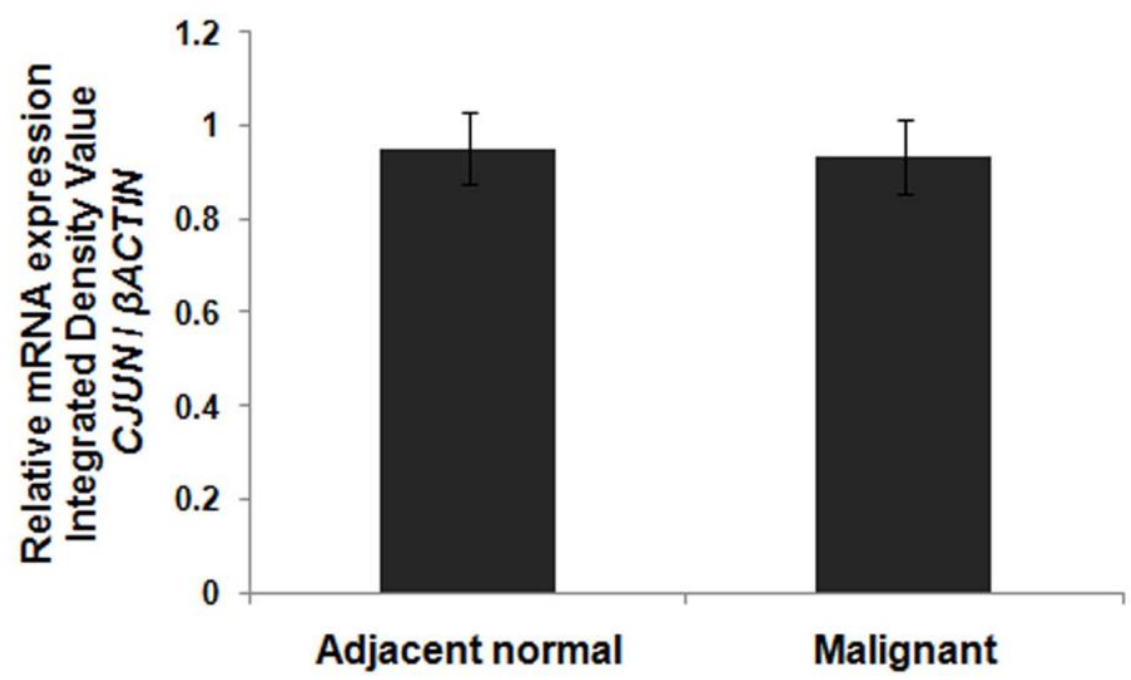

Fig. 3B Graphical representation of CJUN mRNA levels expressed as Integrated Density Values (IDV) in paired malignant and adjacent normal tissues of oral cancer patients

3.3 Levels of $97 \mathrm{kDa}$ truncated E-cadherin and c-Jun protein in malignant and adjacent normal tissues

Fig. 4A and Fig. 4B depicts truncated E-cadherin protein expression by western blot. It revealed that truncated E-cadherin protein expression was significantly increased $(p=0.025)$ in malignant 
Bhairavi N. Vajaria, Kinjal R. Patel, Rasheedunnisa Begum, Franky D. Shah, Jayendra B. Patel, Geeta M. Joshi, and Prabhudas S. Patel / American Journal of Oral medicine (2017) Vol. 3 No. 1 pp. 1-24

tissues as compared to adjacent normal tissues by paired ' $t$ ' test.

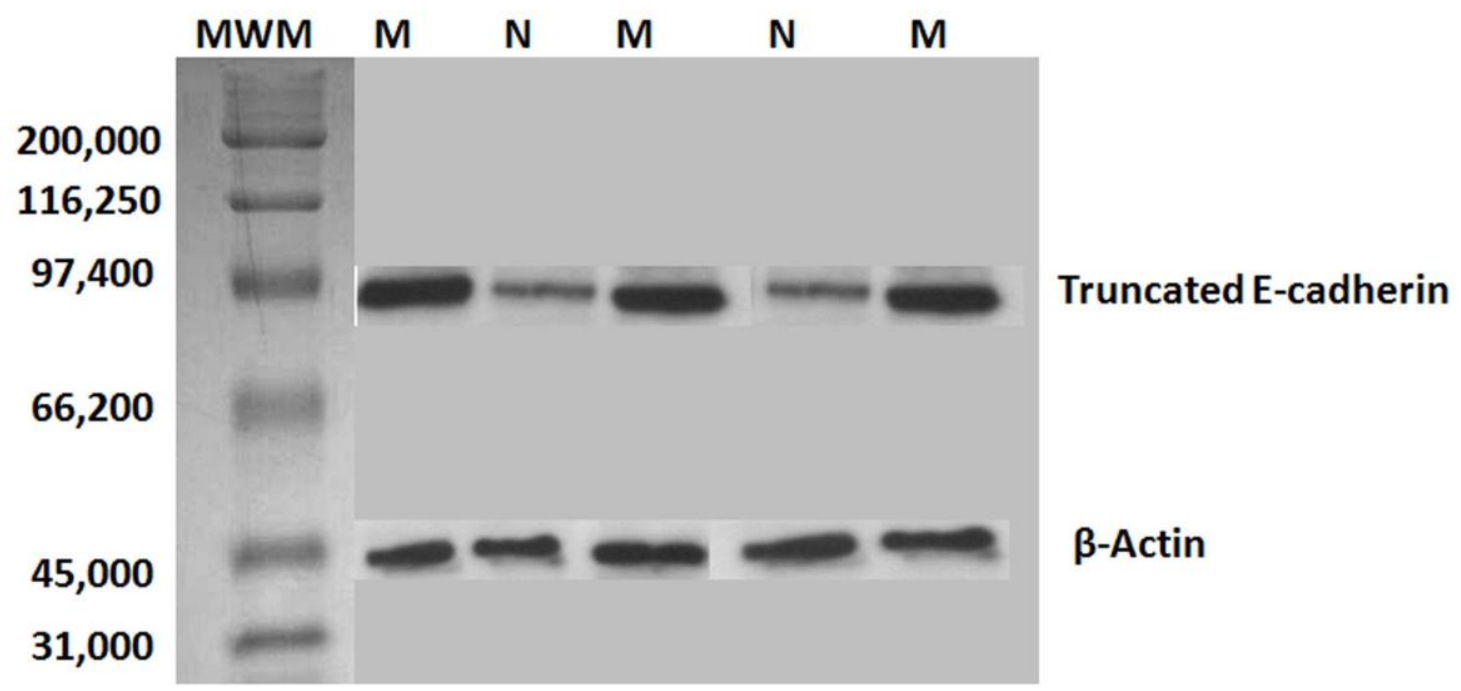

Fig. 4A Representative pattern of truncated $97 \mathrm{kDa}$ E-cadherin protein in adjacent normal and malignant tissues. MWM: Molecular weight marker, $\mathrm{N}=$ Normal, $\mathrm{M}=$ Malignant

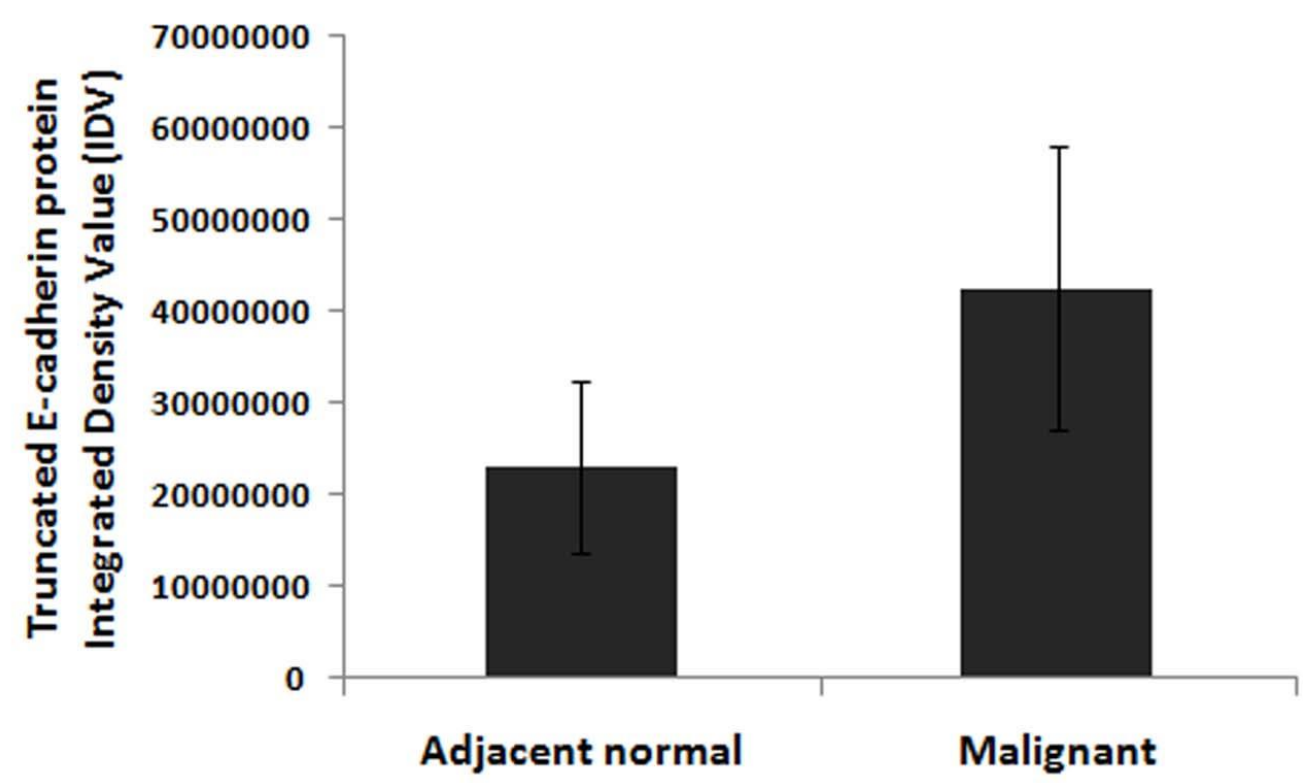

Fig. 4B Graphical representation of truncated E-cadherin expression in paired adjacent normal and malignant tissues expressed as Integrated Density Value (IDV).

The levels of c-Jun protein were compared in malignant and adjacent normal tissues of oral cancer patients. Fig. 5A is the representative of c-Jun protein in malignant and adjacent normal tissues. 
Bhairavi N. Vajaria, Kinjal R. Patel, Rasheedunnisa Begum, Franky D. Shah, Jayendra B. Patel, Geeta M. Joshi, and Prabhudas S. Patel / American Journal of Oral medicine (2017) Vol. 3 No. 1 pp. 1-24

The bar chart in Fig. 5B depicts that the levels of c-Jun protein were found to be significantly higher $(\mathrm{p}=0.031)$ in malignant tissues as compared to adjacent normal tissues by paired $t$-test.

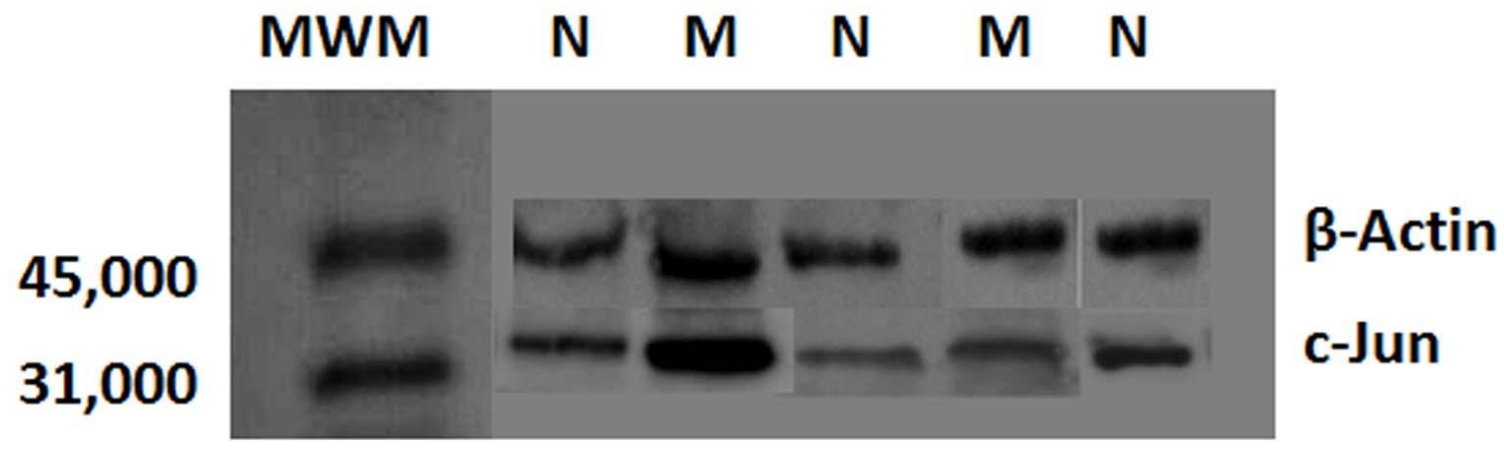

Fig. 5A Representative pattern of c-Jun protein and $\beta$-Actin in adjacent normal and malignant tissues. MWM: Molecular weight marker, $\mathrm{N}=$ Normal, $\mathrm{M}=$ Malignant

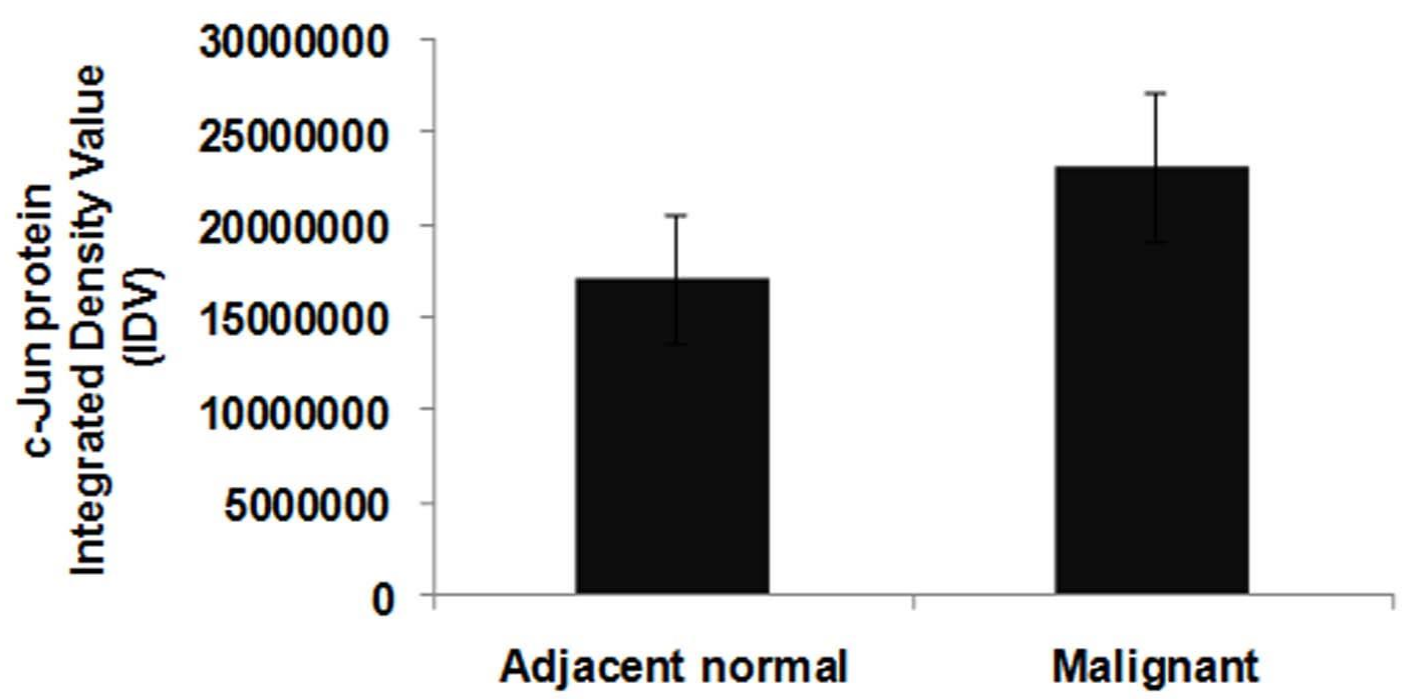

Fig. 5B Graphical representation of c-Jun protein levels in malignant and adjacent normal tissues represented as Integrated Density Value (IDV)

3.4 Correlation of MMP-2, MMP-9, mRNA and protein expression of E-cadherin and c-Jun with various clinicopathological parameters

The levels of different forms of MMPs were further compared in early and advanced stage of disease. The levels of pro MMP-2, active MMP-2, pro MMP-9, Total MMP-2 and total MMP-9 were observed to be higher in advanced stage as compared to early stage of the disease and levels were significant for pro MMP-2 ( $\mathrm{p}=0.003)$ by student's independent ' $t$ ' test. An increasing trend of plasma 
Bhairavi N. Vajaria, Kinjal R. Patel, Rasheedunnisa Begum, Franky D. Shah, Jayendra B. Patel, Geeta M. Joshi, and Prabhudas S. Patel / American Journal of Oral medicine (2017) Vol. 3 No. 1 pp. 1-24

active MMP-2, pro MMP-9, active MMP-9, total MMP-2, total MMP-9 was observed from well to moderate to poorly differentiated tumors.

Multivariate analysis was performed to correlate the markers with various clinico-pathological parameters like stage, differentiation, nuclear grade, metastasis, lymphovascular permeation, lymphocytic infiltration, perineural invasion and infiltration. The results are as depicted in Table 3. Multivariate analysis depicted significant correlation of pro MMP-2, pro MMP-9, active MMP-9 and total MMP-9 ( $\mathrm{p}=0.007, \mathrm{p}=0.052, \mathrm{p}=0.052, \mathrm{p}=0.050$, respectively) with nuclear grade. Active MMP-2 and total MMP-2 was observed to be significantly associated with lymphovascular permeation $(\mathrm{p}=0.053$ and $\mathrm{p}=0.052$ respectively). Pro MMP- 2 was found to be significantly associated with perineural invasion $(\mathrm{p}=0.021)$ and infiltration $(\mathrm{p}=0.053)$.

Moreover, ECAD mRNA expression was found to be lower in infiltrating tumors as compared to non-infiltrating tumors by student's independent ' $t$ ' test, however levels were non-significant. Multivariate analysis showed significant association of ECAD mRNA with differentiation and stage of disease $(\mathrm{p}=0.05$ and $\mathrm{p}=0.048$, respectively). A decreasing trend of ECAD mRNA levels was observed from well to moderate to poorly differentiated tumors, however levels were nonsignificant. The levels were found to be significantly decreased $(p=0.041)$ in moderately differentiated tumors as compared to well differentiated tumors by student's independent ' $t$ ' test.

The results by independent ' $t$ ' test revealed that the levels of truncated E-cadherin protein (97 kDa) were found to be higher in advanced stage of disease as compared to early stage $(\mathrm{p}=0.313)$ of disease. The levels of truncated E-cadherin protein were found to be increased in infiltrative tumors as compared to non-infiltrative tumors $(\mathrm{p}=0.121)$ and were also significantly higher in metastatic tumors as compared to non-metastatic tumors $(\mathrm{p}<0.0001)$. Multivariate analysis depicted significant association of truncated E-cadherin protein with metastasis $(\mathrm{p}<0.0001)$.

Table 3 shows the results of multivariate analysis which depicted significant association of CJUN mRNA with the stage of disease $(\mathrm{p}=0.044)$. c-Jun protein expression was found to be higher in moderately differentiated tumors as compared to well differentiated tumors $(p=0.258)$, however levels were non-significant by student's independent ' $t$ ' test.

Table 3 Multivariate analysis of different forms of plasma MMP-2, MMP-9, E-cadherin and c-Jun with various clinico-pathological parameters

\begin{tabular}{|c|c|c|c|c|c|c|c|c|c|c|}
\hline & $\begin{array}{c}\text { Pro } \\
\text { MMP-2 }\end{array}$ & $\begin{array}{l}\text { Active } \\
\text { MMP-2 }\end{array}$ & $\begin{array}{c}\text { Pro } \\
\text { MMP-9 }\end{array}$ & $\begin{array}{l}\text { Active } \\
\text { MMP-9 }\end{array}$ & $\begin{array}{c}\text { Total } \\
\text { MMP-2 }\end{array}$ & $\begin{array}{c}\text { Total } \\
\text { MMP-9 }\end{array}$ & $\begin{array}{l}\text { CJUN } \\
\text { mRNA }\end{array}$ & $\begin{array}{l}\text { ECAD } \\
\text { mRNA }\end{array}$ & $\begin{array}{c}\text { c-JUN } \\
\text { protein }\end{array}$ & $\begin{array}{c}\text { Truncated } \\
\text { E-cadherin } \\
\text { protein }\end{array}$ \\
\hline Stage & $\begin{array}{l}\mathrm{F}=1.267 \\
\mathrm{p}=0.292\end{array}$ & $\begin{array}{l}\mathrm{F}=0.306 \\
\mathrm{p}=0.821\end{array}$ & $\begin{array}{l}F=0.557 \\
p=0.645\end{array}$ & $\begin{array}{l}\mathrm{F}=0.418 \\
\mathrm{p}=0.740\end{array}$ & $\begin{array}{l}F=0.297 \\
p=0.828\end{array}$ & $\begin{array}{l}F=0.532 \\
p=0.662\end{array}$ & $\begin{array}{l}F=3.452 \\
p=0.044\end{array}$ & $\begin{array}{l}F=3.339 \\
p=0.048\end{array}$ & $\begin{array}{l}F=0.051 \\
p=0.837\end{array}$ & $\begin{array}{l}F=1.643 \\
p=0.236\end{array}$ \\
\hline $\begin{array}{l}\text { Differentia- } \\
\text { tion }\end{array}$ & $\begin{array}{l}\mathrm{F}=1.152 \\
\mathrm{p}=0.321\end{array}$ & $\begin{array}{l}\mathrm{F}=0.457 \\
\mathrm{p}=0.635\end{array}$ & $\begin{array}{l}\mathrm{F}=2.022 \\
\mathrm{p}=0.139\end{array}$ & $\begin{array}{l}F=2.504 \\
p=0.088\end{array}$ & $\begin{array}{l}F=0.478 \\
p=0.622\end{array}$ & $\begin{array}{l}F=2.139 \\
p=0.124\end{array}$ & $\begin{array}{l}F=0.180 \\
p=0.837\end{array}$ & $\begin{array}{l}F=3.670 \\
p=0.050\end{array}$ & $\begin{array}{l}F=0.368 \\
p=0.537\end{array}$ & $\begin{array}{l}F=1.081 \\
p=0.329\end{array}$ \\
\hline $\begin{array}{l}\text { Nuclear } \\
\text { grade }\end{array}$ & $\begin{array}{l}F=5.337 \\
p=0.007\end{array}$ & $\begin{array}{l}F=1.354 \\
p=0.266\end{array}$ & $\begin{array}{l}F=3.118 \\
p=0.052\end{array}$ & $\begin{array}{l}F=3.116 \\
p=0.052\end{array}$ & $\begin{array}{l}F=2.117 \\
p=0.130\end{array}$ & $\begin{array}{l}F=3.164 \\
p=0.050\end{array}$ & $\begin{array}{l}F=0.027 \\
P=0.871\end{array}$ & $\begin{array}{l}F=1.136 \\
p=0.303\end{array}$ & $\begin{array}{l}F=1.305 \\
p=0.336\end{array}$ & $\begin{array}{l}F=2.816 \\
p=0.144\end{array}$ \\
\hline
\end{tabular}


Bhairavi N. Vajaria, Kinjal R. Patel, Rasheedunnisa Begum, Franky D. Shah, Jayendra B. Patel, Geeta M. Joshi, and Prabhudas S. Patel / American Journal of Oral medicine (2017) Vol. 3 No. 1 pp. 1-24

\begin{tabular}{|c|c|c|c|c|c|c|c|c|c|c|}
\hline Metastasis & $\begin{array}{l}F=0.869 \\
p=0.423\end{array}$ & $\begin{array}{l}F=0.670 \\
p=0.514\end{array}$ & $\begin{array}{l}F=0.372 \\
p=0.690\end{array}$ & $\begin{array}{l}F=0.682 \\
p=0.508\end{array}$ & $\begin{array}{l}F=0.738 \\
p=0.481\end{array}$ & $\begin{array}{l}F=0.432 \\
p=0.650\end{array}$ & $\begin{array}{l}F=0.002 \\
p=0.969\end{array}$ & $\begin{array}{l}F=0.158 \\
p=0.696\end{array}$ & $\begin{array}{l}F=0.194 \\
p=0.689\end{array}$ & $\begin{array}{l}F=43.778 \\
p<0.0001\end{array}$ \\
\hline $\begin{array}{c}\text { Lympho- } \\
\text { vascular } \\
\text { permeation }\end{array}$ & $\begin{array}{l}F=0.021 \\
p=0.885\end{array}$ & $\begin{array}{l}F=3.866 \\
p=0.053\end{array}$ & $\begin{array}{l}F=0.334 \\
p=0.565\end{array}$ & $\begin{array}{l}F=0.322 \\
p=0.572\end{array}$ & $\begin{array}{l}F=3.102 \\
p=0.052\end{array}$ & $\begin{array}{l}F=0.336 \\
p=0.563\end{array}$ & $\begin{array}{l}F=0.986 \\
p=0.336\end{array}$ & $\begin{array}{l}F=0.336 \\
p=0.787\end{array}$ & $\begin{array}{l}F=0.002 \\
p=0.970\end{array}$ & $\begin{array}{l}F=0.120 \\
p=0.737\end{array}$ \\
\hline $\begin{array}{l}\text { Lymphocytic } \\
\text { stromal } \\
\text { response }\end{array}$ & $\begin{array}{l}F=1.174 \\
p=0.282\end{array}$ & $\begin{array}{l}F=1.420 \\
p=0.237\end{array}$ & $\begin{array}{l}F=0.398 \\
p=0.530\end{array}$ & $\begin{array}{l}F=0.196 \\
p=0.659\end{array}$ & $\begin{array}{l}F=0.846 \\
p=0.360\end{array}$ & $\begin{array}{l}F=0.357 \\
p=0.552\end{array}$ & $\begin{array}{l}F=0.892 \\
p=0.358\end{array}$ & $\begin{array}{l}F=0.087 \\
p=0.771\end{array}$ & $\begin{array}{l}F=0.184 \\
p=0.697\end{array}$ & $\begin{array}{l}F=0.096 \\
p=0.764\end{array}$ \\
\hline $\begin{array}{c}\text { Perineural } \\
\text { invasion }\end{array}$ & $\begin{array}{l}F=5.560 \\
p=0.021\end{array}$ & $\begin{array}{l}F=1.748 \\
p=0.190\end{array}$ & $\begin{array}{l}F=0.286 \\
p=0.594\end{array}$ & $\begin{array}{l}F=0.208 \\
p=0.650\end{array}$ & $\begin{array}{l}F=2.411 \\
p=0.124\end{array}$ & $\begin{array}{l}F=0.274 \\
p=0.602\end{array}$ & $\begin{array}{l}F=0.357 \\
p=0.559\end{array}$ & $\begin{array}{l}\mathrm{F}=0.222 \\
\mathrm{p}=0.644\end{array}$ & $\begin{array}{l}F=0.029 \\
p=0.889\end{array}$ & $\begin{array}{l}F=0.327 \\
p=0.582\end{array}$ \\
\hline $\begin{array}{c}\text { Infiltration } \\
\text { (muscles) }\end{array}$ & $\begin{array}{l}F=3.863 \\
p=0.053\end{array}$ & $\begin{array}{l}F=0.125 \\
p=0.724\end{array}$ & $\begin{array}{l}F=0.664 \\
p=0.418\end{array}$ & $\begin{array}{l}F=0.056 \\
p=0.813\end{array}$ & $\begin{array}{l}F=0.001 \\
p=0.971\end{array}$ & $\begin{array}{l}F=0.495 \\
p=0.483\end{array}$ & $\begin{array}{l}F=0.131 \\
p=0.723\end{array}$ & $\begin{array}{l}F=0.761 \\
p=0.390\end{array}$ & $\begin{array}{l}F=1.230 \\
p=0.348\end{array}$ & $\begin{array}{l}F=1.432 \\
p=0.262\end{array}$ \\
\hline
\end{tabular}

\subsection{ROC curve analysis of plasma pro, active and total MMP-2 and MMP-9}

ROC curves were constructed for plasma pro, active and total MMP-2 and MMP-9 (Table 4). The results revealed that pro MMP-2, active MMP-2, pro MMP-9, active MMP-9, total MMP-2 and total MMP-9 could significantly distinguish controls and patients with OPC $(\mathrm{p}<0.0001, \mathrm{p}<0.0001$, $\mathrm{p}<0.0001, \mathrm{p}=0.002, \mathrm{p}<00.001, \mathrm{p}<0.0001$ respectively). Pro MMP-2, active MMP-2, pro MMP-9, total MMP-2 and total MMP-9 could significantly discriminate controls and oral cancer patients $(\mathrm{p}<0.0001, \mathrm{p}<0.0001, \mathrm{p}<0.0001, \mathrm{p}<0.0001, \mathrm{p}=0.006$ respectively). Moreover, pro MMP-2, pro MMP9, active MMP-9 and total MMP-9 could significantly distinguish patients with OPC and oral cancer patients $(\mathrm{p}<0.0001, \mathrm{p}<0.0001, \mathrm{p}=0.003$ and $\mathrm{p}<0.0001$, respectively).

Table 4 ROC curve analysis of plasma pro, active and total MMP-2 and MMP-9

\begin{tabular}{|l|l|c|c|c|c|c|c|}
\hline \multicolumn{1}{|c|}{$\begin{array}{c}\text { Groups } \\
\text { compared }\end{array}$} & $\begin{array}{c}\text { Pro } \\
\text { MMP-2 }\end{array}$ & $\begin{array}{c}\text { Active } \\
\text { MMP-2 }\end{array}$ & $\begin{array}{c}\text { Pro } \\
\text { MMP-9 }\end{array}$ & $\begin{array}{c}\text { Active } \\
\text { MMP-9 }\end{array}$ & $\begin{array}{c}\text { Total } \\
\text { MMP-2 }\end{array}$ & $\begin{array}{c}\text { Total } \\
\text { MMP-9 }\end{array}$ \\
\hline $\begin{array}{l}\text { Controls vs. } \\
\text { patients with } \\
\text { OPC }\end{array}$ & $\begin{array}{l}\text { AUC } \\
\text { Significance }\end{array}$ & $\begin{array}{c}0.736 \\
\mathrm{p}<0.0001\end{array}$ & $\begin{array}{c}0.893 \\
\mathrm{p}<0.0001\end{array}$ & $\begin{array}{c}0.901 \\
\mathrm{p}<0.0001\end{array}$ & $\begin{array}{c}0.664 \\
\mathrm{p}=0.002\end{array}$ & $\begin{array}{c}0.877 \\
\mathrm{p}<0.0001\end{array}$ & $\begin{array}{c}0.901 \\
\mathrm{p}<0.0001\end{array}$ \\
\hline $\begin{array}{l}\text { Controls vs. oral } \\
\text { cancer patients }\end{array}$ & AUC Significance & $\begin{array}{c}0.657 \\
\mathrm{p}<0.0001\end{array}$ & $\begin{array}{c}0.810 \\
\mathrm{p}<0.0001\end{array}$ & $\begin{array}{c}0.730 \\
\mathrm{p}<0.0001\end{array}$ & $\begin{array}{c}0.512 \\
\mathrm{p}=0.789\end{array}$ & $\begin{array}{c}0.757 \\
\mathrm{p}<0.0001\end{array}$ & $\begin{array}{c}0.621 \\
\mathrm{p}=0.006\end{array}$ \\
\hline $\begin{array}{l}\text { Patients with } \\
\text { OPC vs. oral } \\
\text { cancer patients }\end{array}$ & $\begin{array}{l}\text { AUC } \\
\text { Significance }\end{array}$ & $\begin{array}{c}0.267 \\
\mathrm{p}<0.0001\end{array}$ & $\begin{array}{c}0.452 \\
\mathrm{p}=0.335\end{array}$ & $\begin{array}{c}0.305 \\
\mathrm{p}<0.0001\end{array}$ & $\begin{array}{c}\mathrm{p}=0.353 \\
\mathrm{p}=0.003\end{array}$ & $\begin{array}{c}0.443 \\
\mathrm{p}=0.225\end{array}$ & $\begin{array}{c}0.322 \\
\mathrm{p}<0.0001\end{array}$ \\
\hline
\end{tabular}

\subsection{Pearson's correlation between E-cadherin Protein and mRNA, CJUN mRNA and Protein}

No significant correlation was observed between CJUN mRNA and protein $(\mathrm{r}=0.021, \mathrm{p}=0.933)$. The pearson's correlation analysis between E-cadherin and c-Jun protein expression as well as its mRNA expression depicted (Table 5) a significant positive correlation between E-cadherin protein 
Bhairavi N. Vajaria, Kinjal R. Patel, Rasheedunnisa Begum, Franky D. Shah, Jayendra B. Patel, Geeta M. Joshi, and Prabhudas S. Patel / American Journal of Oral medicine (2017) Vol. 3 No. 1 pp. 1-24

and CJUN mRNA ( $\mathrm{r}=0.826, \mathrm{p}=0.006)$. A significant positive correlation of truncated E-cadherin protein ( $\mathrm{r}=0.826, \mathrm{p}=0.006)$ was observed with CJUN mRNA. Moreover, ECAD mRNA was observed to be positively correlated with CJUN mRNA ( $\mathrm{r}=0.193, \mathrm{p}=0.378)$. Truncated E-cadherin protein exhibited positive correlation with c-Jun protein ( $\mathrm{r}=0.261, \mathrm{p}=0.533)$.

Table 5 Pearson's correlation analysis of Plasma MMPs with E-cadherin and c-Jun protein and mRNA

\begin{tabular}{|l|c|c|c|c|}
\hline & $\begin{array}{c}\text { CJUN } \\
\text { mRNA }\end{array}$ & $\begin{array}{c}\text { c-Jun } \\
\text { protein }\end{array}$ & $\begin{array}{c}\text { ECAD } \\
\text { mRNA }\end{array}$ & $\begin{array}{c}\text { E-cadherin } \\
\text { Protein }\end{array}$ \\
\hline Plasma pro MMP-2 & $\mathrm{r}=0.158$ & $\mathrm{r}=0.013$ & $\mathrm{r}=0.277$ & $\mathrm{r}=0.948$ \\
& $\mathrm{p}=0.450$ & $\mathrm{p}=0.958$ & $\mathrm{p}=0.237$ & $\mathrm{p}<0.0001$ \\
\hline Plasma active MMP-2 & $\mathrm{r}=0.197$ & $\mathrm{r}=0.167$ & $\mathrm{r}=-0.024$ & $\mathrm{r}=0.748$ \\
& $\mathrm{p}=0.346$ & $\mathrm{p}=0.508$ & $\mathrm{p}=0.919$ & $\mathrm{p}=0.008$ \\
\hline Plasma pro MMP-9 & $\mathrm{r}=0.163$ & $\mathrm{r}=0.181$ & $\mathrm{r}=-0.089$ & $\mathrm{r}=0.210$ \\
& $\mathrm{p}=0.435$ & $\mathrm{p}=0.472$ & $\mathrm{p}=0.708$ & $\mathrm{p}=0.535$ \\
\hline Plasma active MMP-9 & $\mathrm{r}=0.228$ & $\mathrm{r}=0.372$ & $\mathrm{r}=-0.040$ & $\mathrm{r}=0.873$ \\
& $\mathrm{p}=0.273$ & $\mathrm{p}=0.129$ & $\mathrm{p}=0.867$ & $\mathrm{p}<0.0001$ \\
\hline Plasma total MMP-2 & $\mathrm{r}=0.200$ & $\mathrm{r}=0.126$ & $\mathrm{r}=0.045$ & $\mathrm{r}=0.778$ \\
& $\mathrm{p}=0.338$ & $\mathrm{p}=0.619$ & $\mathrm{p}=0.851$ & $\mathrm{p}=0.005$ \\
\hline Plasma total MMP-9 & $\mathrm{r}=0.182$ & $\mathrm{r}=0.232$ & $\mathrm{r}=-0.079$ & $\mathrm{r}=0.0062$ \\
& $\mathrm{p}=0.383$ & $\mathrm{p}=0.355$ & $\mathrm{p}=0.741$ & $\mathrm{p}=0.857$ \\
\hline Plasma activation ratio MMP-2 & $\mathrm{r}=-0.162$ & $\mathrm{r}=0.017$ & $\mathrm{r}=-0.412$ & $\mathrm{r}=0.647$ \\
& $\mathrm{p}=0.440$ & $\mathrm{p}=0.947$ & $\mathrm{p}=0.071$ & $\mathrm{p}=0.031$ \\
\hline Plasma activation ratio MMP-9 & $\mathrm{r}=0.137$ & $\mathrm{r}=0.176$ & $\mathrm{r}=0.134$ & $\mathrm{r}=0.105$ \\
& $\mathrm{p}=0.515$ & $\mathrm{p}=0.484$ & $\mathrm{p}=0.573$ & $\mathrm{p}=0.773$ \\
\hline E-cadherin Protein & $\mathrm{r}=0.826$ & $\mathrm{r}=0.261$ & $\mathrm{r}=0.110$ & \\
& $\mathrm{p}=0.006$ & $\mathrm{p}=0.533$ & $\mathrm{p}=0.795$ & --- \\
\hline E-cadherin mRNA & $\mathrm{r}=0.193$ & $\mathrm{r}=0.053$ & & $\mathrm{r}=0.110$ \\
& $\mathrm{p}=0.378$ & $\mathrm{p}=0.858$ & ---- & $\mathrm{p}=0.795$ \\
\hline CJUN mRNA & ---- & $\mathrm{r}=0.021$ & $\mathrm{r}=0.193$ & $\mathrm{r}=0.826$ \\
& $\mathrm{p}=0.021$ & $\mathrm{p}=0.933$ & $\mathrm{p}=0.378$ & $\mathrm{p}=0.006$ \\
\hline c-Jun protein & $\mathrm{p}=0.933$ & ---- & $\mathrm{r}=0.053$ & $\mathrm{r}=0.261$ \\
& & & $\mathrm{p}=0.858$ & $\mathrm{p}=0.533$ \\
\hline
\end{tabular}

3.6 Pearson's correlation analysis of plasma MMPs with E-cadherin and c-Jun protein and mRNA

As depicted in Table 5, truncated E-cadherin protein showed significant positive correlation with plasma pro MMP-2 ( $\mathrm{r}=0.948, \mathrm{p}<0.0001)$, plasma active MMP-2 ( $\mathrm{r}=0.748, \mathrm{p}=0.008)$, plasma active MMP-9 ( $\mathrm{r}=0.873, \mathrm{p}<0.0001)$, plasma total MMP-2 ( $\mathrm{r}=0.778, \mathrm{p}=0.005)$ and activation ratio MMP-2 $(\mathrm{r}=0.062, \mathrm{p}=0.857)$. Moreover, all the forms of plasma MMPs were positively correlated with c-Jun protein and mRNA levels, although the correlation was observed to be non-significant. Plasma active MMP-2, pro MMP-9, active MMP-9, total MMP-9 and activation ratio MMP-2 were observed to be negatively correlated with ECAD mRNA, however, the correlation was non-significant. 
Bhairavi N. Vajaria, Kinjal R. Patel, Rasheedunnisa Begum, Franky D. Shah, Jayendra B. Patel, Geeta M. Joshi, and Prabhudas S. Patel / American Journal of Oral medicine (2017) Vol. 3 No. 1 pp. 1-24

3.7 Kaplan Meier's survival analysis of different forms of plasma MMPs, E-cadherin and c-Jun protein and $m R N A$ with overall survival

Kaplan Meier's survival analysis was carried out to estimate the overall survival of oral cancer patients. Survival analysis depicted that the oral cancer patients with values above ROC cut-off of active MMP-2, pro MMP-9, total MMP-2 and total MMP-9 (Table 6) had lower overall survival as compared to those with values below ROC cut-off.

Table 6 Survival analysis of different forms of plasma MMPs, c-Jun, E-cadherin mRNA and protein using ROC cut-off

\begin{tabular}{|c|c|c|c|c|c|c|}
\hline Parameters & $\begin{array}{c}\text { ROC cut- } \\
\text { off } \\
\text { (AUC) }\end{array}$ & $\begin{array}{l}\text { ROC cut-off } \\
\text { Sensitivity/ } \\
\text { specificity } \\
\text { p-value }\end{array}$ & $\begin{array}{l}\text { Below cut- } \\
\text { off } \\
\text { Survival } \\
\text { estimate } \\
\text { (months) } \pm \\
\text { SEM } \\
\end{array}$ & $\begin{array}{c}\text { Above cut-off } \\
\text { Survival } \\
\text { (months) } \\
\text { estimate } \pm \\
\text { SEM }\end{array}$ & $\begin{array}{c}\text { Log rank } \\
\text { (Mantel } \\
\text { Cox) Chi }{ }^{2}\end{array}$ & $p$-value \\
\hline Pro MMP-2 & $\begin{array}{c}3360 \\
(0.657)\end{array}$ & $\begin{array}{c}96.04 \% / 51.35 \% \\
p=0.0009\end{array}$ & --- & ---- & 0.134 & $\mathrm{p}=0.714$ \\
\hline Active MMP-2 & $\begin{array}{c}13248 \\
(0.810)\end{array}$ & $\begin{array}{c}77.23 \% / 70.27 \% \\
\mathrm{p}<0.0001\end{array}$ & $41.282 \pm 3.688$ & $39.359 \pm 2.177$ & 0.449 & $\mathrm{p}=0.503$ \\
\hline Pro MMP-9 & $\begin{array}{c}9680 \\
(0.730)\end{array}$ & $\begin{array}{c}82.2 \% / 55.4 \% \\
p<0.0001\end{array}$ & $48.00 \pm 0.00$ & $38.248 \pm 1.982$ & 2.314 & $\mathrm{p}=0.128$ \\
\hline Active MMP-9 & $\begin{array}{c}18360 \\
(0.512)\end{array}$ & $\begin{array}{c}72.28 \% / 4.05 \% \\
p=0.7898\end{array}$ & $39.269 \pm 2.518$ & $39.122 \pm 2.585$ & 0.118 & $\mathrm{p}=0.731$ \\
\hline Total MMP-2 & $\begin{array}{c}24382 \\
(0.757)\end{array}$ & $\begin{array}{c}62.38 \% / 74.32 \% \\
\mathrm{p}<0.0001\end{array}$ & $43.767 \pm 2.639$ & $35.889 \pm 2.316$ & 2.826 & $\mathrm{p}=0.093$ \\
\hline Total MMP-9 & $\begin{array}{c}39832 \\
(0.621) \\
\end{array}$ & $\begin{array}{c}45.54 \% / 83.78 \% \\
p=0.0041\end{array}$ & $40.267 \pm 2.785$ & $37.732 \pm 2.414$ & 0.103 & $\mathrm{p}=0.748$ \\
\hline $\begin{array}{l}\text { Activation ratio } \\
\text { MMP-2 }\end{array}$ & $\begin{array}{c}0.475 \\
(0.517) \\
\end{array}$ & $\begin{array}{c}99.01 \% / 32.43 \% \\
p=0.7381\end{array}$ & $-\cdots--$ & ---- & 0.407 & $\mathrm{p}=0.816$ \\
\hline $\begin{array}{l}\text { Activation ratio } \\
\text { MMP-9 }\end{array}$ & $\begin{array}{c}0.35 \\
(0.752) \\
\end{array}$ & $\begin{array}{c}93.07 \% / 50.0 \% \\
p<0.0001\end{array}$ & $-\cdots--$ & ----- & 0.675 & $\mathrm{p}=0.411$ \\
\hline CJUN mRNA & $\begin{array}{c}0.666 \\
(0.542)\end{array}$ & $\begin{array}{c}76.2 \% / 40.0 \% \\
p=0.5178\end{array}$ & $36.714 \pm 4.894$ & $36.931 \pm 4.079$ & 0.012 & $\mathrm{p}=0.911$ \\
\hline c-Jun protein & $\begin{array}{c}20169184 \\
(0.548) \\
\end{array}$ & $\begin{array}{c}40.0 \% / 82.6 \% \\
p=0.5792\end{array}$ & $-\cdots--$ & ---- & 7.038 & $\mathrm{p}=0.008$ \\
\hline $\begin{array}{l}\text { Truncated } \\
\text { E-cadherin } \\
\text { protein }\end{array}$ & $\begin{array}{c}3523968 \\
(0.673)\end{array}$ & $\begin{array}{c}100 \% / 26.8 \% \\
p=0.2602\end{array}$ & $-\cdots--$ & ----- & 0.400 & $p=0.527$ \\
\hline$E C A D$ mRNA & $\begin{array}{c}0.272 \\
(0.570)\end{array}$ & $\begin{array}{l}66.7 / 57.6 \\
p=0.3416\end{array}$ & $36.0 \pm 6.928$ & $40.282 \pm 3.139$ & 0.182 & $\mathrm{p}=0.670$ \\
\hline
\end{tabular}

Kaplan Meier's survival analysis of ECAD mRNA depicted lower survival with lower ECAD mRNA levels (values below ROC cut-off) (Fig. 6A). Fig. 6B depicted that higher levels of truncated Ecadherin protein (above ROC cutoff) had lower overall survival as compared to lower levels (below cut-off). The ROC cut-off values with sensitivity, specificity and AUC along with Log Rank Chi ${ }^{2}$ value are as mentioned in Table 6. 
Bhairavi N. Vajaria, Kinjal R. Patel, Rasheedunnisa Begum, Franky D. Shah, Jayendra B. Patel, Geeta M. Joshi, and Prabhudas S. Patel / American Journal of Oral medicine (2017) Vol. 3 No. 1 pp. 1-24
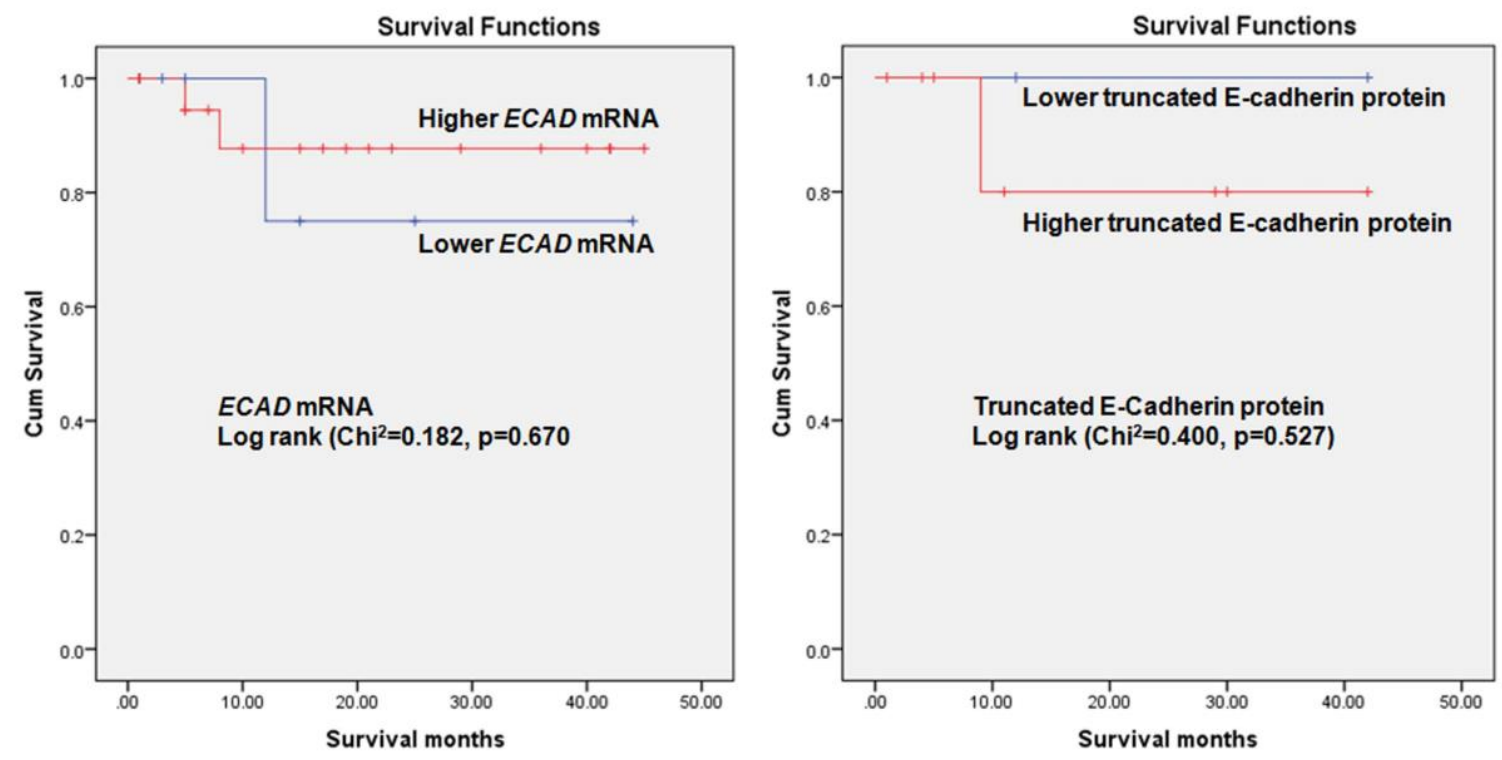

Fig. 6. Kaplan Meir's Survival curves of (A) ECAD mRNA and (B) truncated E-cadherin protein.

Kaplan Meier survival curves were compared by Log-rank analysis and ECAD mRNA and truncated E-cadherin protein expression levels in oral cancer patients were depicted as higher (above ROC cut-off) or lower levels (below ROC cut-off). The values above and below cutoff are expressed as survival in months \pm SEM.

Fig. 7A depicted no significant association of CJUN mRNA with overall survival. Fig. 7B and Table 6 revealed that higher values of c-Jun protein expression depicted significant association with overall survival $\left(\mathrm{Chi}^{2}=7.038, \mathrm{p}=0.008\right)$.

Kaplan Meier's Survival mean estimate of E-cadherin protein, c-Jun, pro MMP-2, activation ratio MMP-2, activation ratio MMP-9 cannot be computed as all the cases were censored. 
Bhairavi N. Vajaria, Kinjal R. Patel, Rasheedunnisa Begum, Franky D. Shah, Jayendra B. Patel, Geeta M. Joshi, and Prabhudas S. Patel / American Journal of Oral medicine (2017) Vol. 3 No. 1 pp. 1-24
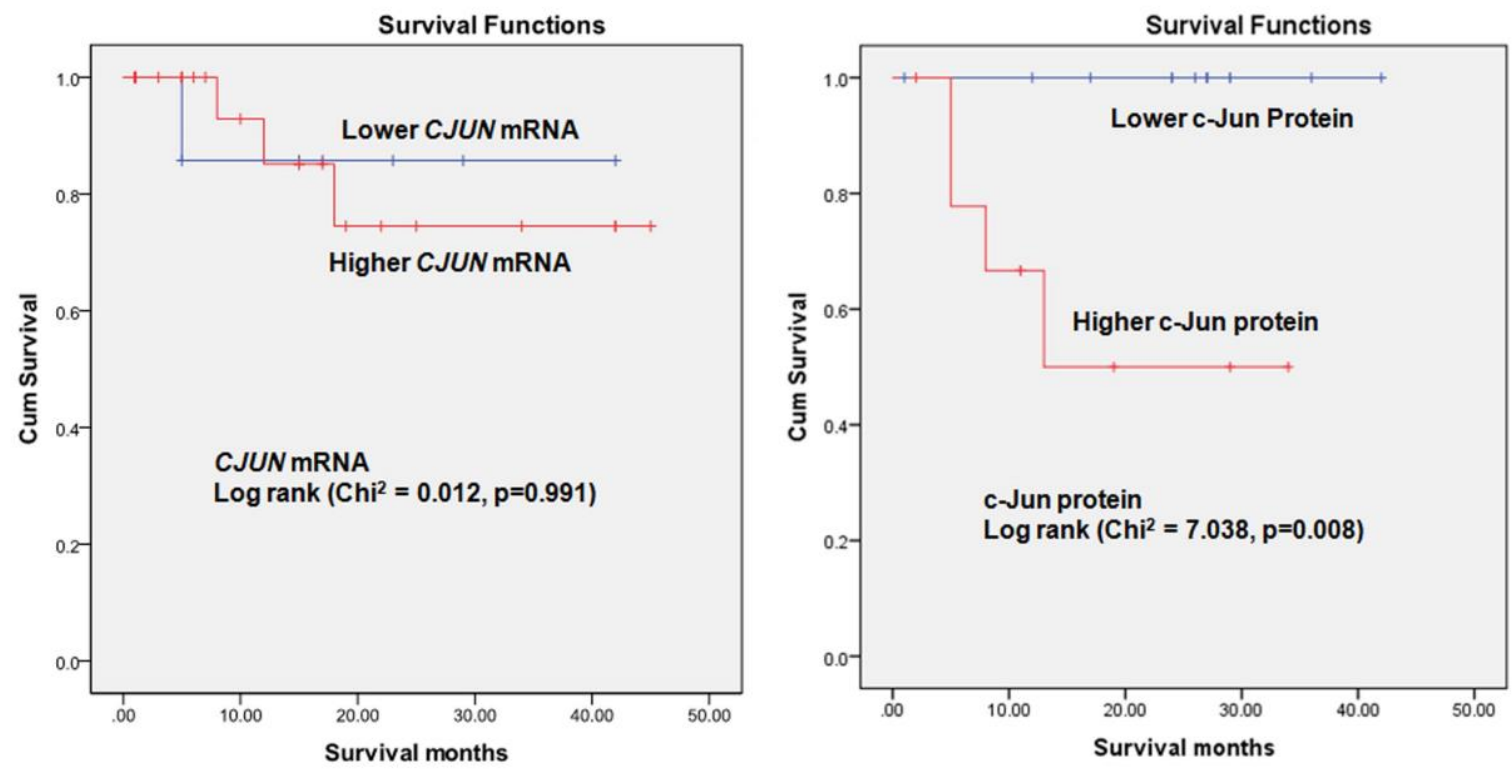

Fig. 7. Kaplan Meier's survival analysis of (A) CJUN mRNA and (B) c-Jun protein. Kaplan Meier survival curves were compared by Log-rank analysis and CJUN mRNA and protein expression levels in oral cancer patients were depicted as higher (values above ROC cut-off) or lower (values below ROC cut-off value) values. The values are expressed as survival in months \pm SEM.

\section{Discussion}

Loss of E-cadherin mediated cell-cell adhesion plays a key role in metastasis. Recently cell lines based studies have documented that loss of E-cadherin mediates increase in c-Jun protein with no corresponding increase in c-Jun mRNA in melanoma and glioblastoma (Blau et al., 2012; Splangler et al., 2011). As MMPs play a crucial role in disruption of cell-cell adhesion, the present study was designed for simultaneous evaluation of E-cadherin and c-Jun protein and mRNA expression along with MMPs in oral cancer patients. To our knowledge there are lack of studies evaluating simultaneously all these parameters in oral cancer. Initially MMPs were thought to be important exclusively in invasion and metastasis, but recent studies have demonstrated that MMPs play a role in several steps during carcinogenesis (Yadav et al., 2014; Shrestha et al., 2014). In the present study, the levels of pro, active and total MMP-2 and MMP-9 were significantly higher in patients with OPC as compared to controls. Active MMP-2 was observed to be significantly higher in oral cancer patients as compared to patients with OPC. Increase in the expression of MMP-2 and MMP-9 have been recently reported in oral precancerous conditions and various intermediate stages of oral carcinogenensis (Shrestha et al., 2014; Al-Rawi et al., 2014). In the present study, the results demonstrated significant higher levels of active MMP-2, pro and active MMP-9, total MMP-2 and MMP-9 in oral cancer patients as compared to controls. The results were consistent with our previous results which depicted upregulation of MMP-2 and MMP-9 in oral cancer (Shrestha et al., 2014). Earlier studies have observed that MMP-9 expression was associated with tumor metastasis of oral squamous cell carcinoma (OSCC) (Tao et al., 2014; Specenier et al., 2015). 
Bhairavi N. Vajaria, Kinjal R. Patel, Rasheedunnisa Begum, Franky D. Shah, Jayendra B. Patel, Geeta M. Joshi, and Prabhudas S. Patel / American Journal of Oral medicine (2017) Vol. 3 No. 1 pp. 1-24

The present study depicted higher levels of pro MMP-2, active MMP-2, pro MMP-9, total MMP-2 and total MMP-9 in advanced stage as compared to early stage of disease and levels were significant for pro MMP-2. Earlier studies have shown that high tumor and stromal MMP-2 and MMP-9 expression was significantly associated with positive lymph node metastasis (Fan et al., 2012) and is linked to poor clinical outcomes (Zheng et al., 2015). In the present study, survival analysis depicted that higher values of active MMP-2, pro MMP-9, total MMP-2 and total MMP-9 was associated with lower overall survival. Earlier studies have shown that overall survival was significantly shorter in patients with high tumor and stromal MMP-2 and MMP-9 expression (Fan et al., 2012).

Western blot analysis of E-cadherin revealed significant increase of truncated $97 \mathrm{kDa}$ E-cadherin protein in malignant tissues as compared to adjacent normal tissues. Earlier $97 \mathrm{kDa}$, a truncated form of mature $120 \mathrm{kDa}$ E-cadherin has been documented to be significantly increased in prostate cancer tumors (Rashid et al., 2001). Diminished E-cadherin levels have been reported in oral cancer (Shah et al., 2009, Vered et al., 2012, De Freitas Silva et al., 2014, Zhou et al., 2015) Earlier studies have reported decreased E-cadherin levels in oral precancerous conditions (Freitas Silva et al., 2014, Kaur et al., 2013).

The levels of truncated E-cadherin protein $(97 \mathrm{kDa})$ were found to be higher in advanced disease, infiltrative and metastatic tumors as compared to early disease, non-infiltrative and non-metastatic tumors respectively. The data were consistent with our earlier studies which earlier have reported positive correlation of $97 \mathrm{kDa}$ truncated E-cadherin protein with advanced stage and lymph node metastasis (Shah et al., 2009). Earlier studies have documented E-cadherin in non-tumor epithelium adjacent to oral cancer as a risk marker for the development of multiple tumors (Zhou et al., 2015). However, no correlation between loss of E-cadherin and degree of dysplasia/ tumor differentiation has also been observed earlier (Sridevi et al., 2015).

The levels of $E C A D$ mRNA were analyzed by semiquantitative RT-PCR and the results revealed that the ECAD mRNA levels were comparable between malignant and adjacent normal tissues. Earlier studies have reported downregulation of ECAD mRNA levels. No significant difference was observed in normal and tumor tissues in breast cancer patients in earlier studies by Goyal et al. (Goyal et al., 2008). Lower E-cadherin mRNA and protein levels have been reported in colorectal cancer (Garinis et al., 2003). Earlier reports have suggested that promoter hypermethylation reduces the expression of E-cadherin leading to increased metastasis (Kwon et al. 2010). Moreover, in the present study, ECAD mRNA expression was found to be lower in infiltrating tumors as compared to non-infiltrating tumors. Multivariate analysis showed significant association of $E C A D$ mRNA with differentiation and stage of disease. Earlier studies have reported that mRNA levels of $E C A D$ decreased significantly in metastatic tumors as compared to non-metastatic tumors in nasopharyngeal carcinoma (Kaur et al., 2009). In the present study, Kaplan Meir's survival analysis indicated that lower ECAD mRNA expression depicted lower survival. Earlier studies by Dorudi et al. (Dorudi et al., 1995) have documented that colorectal cancer patients with higher levels of $E C A D$ mRNA had higher overall survival (greater than 5 years). Earlier studies in various types of carcinomas, including oral squamous cell carcinoma (OSCC), by immunohistochemical analysis have shown that reduced expression of E-cadherin protein was associated with poor prognosis (Luo et al., 2014), however its mRNA levels were not studied. 
Bhairavi N. Vajaria, Kinjal R. Patel, Rasheedunnisa Begum, Franky D. Shah, Jayendra B. Patel, Geeta M. Joshi, and Prabhudas S. Patel / American Journal of Oral medicine (2017) Vol. 3 No. 1 pp. 1-24

In the present study, the levels of CJUN mRNA were comparable between paired malignant and adjacent normal tissues. Recent cell lines based studies have shown that there was no change in CJUN mRNA levels in glioblastoma and melanoma, but there was an increase in translatability of CJUN transcript which was suggested to be due IRES mediated translation (Blau et al., 2012; Splangler et al., 2011). In the present study, it was observed that the levels of c-Jun protein were found to be significantly higher in malignant tissues as compared to adjacent normal tissues. Earlier studies have observed higher expression of c-Jun protein oral cancer tissues (Mishra et al., 2010). Another immunohistochemical analysis has shown that nuclear localization of c-Jun protein was linked to development of oral cancer (De Sousa et al., 2002). In the present study, the higher values of c-Jun protein were significantly associated with reduced overall survival. Earlier studies have reported increased positive pc-Jun staining which served as a marker for worse prognosis in OSCC (Kuo et al., 2006) and oral leukoplakias (Lima et al., 2015).

The present study depicted a significant positive correlation between truncated E-cadherin protein and CJUN mRNA. Moreover, ECAD mRNA was observed to be positively correlated with CJUN mRNA. However, there are lack of reports on simultaneous evaluation of mRNA and protein expression of E-cadherin and c-Jun in oral cancer. Earlier studies have observed that loss of E-cadherin mediated cell-cell adhesion is responsible for upregulation of c-Jun protein, which might be due to IRES mediated translation (Knirsh et al., 2009). In the present study, truncated E-cadherin protein was observed to be positively correlated with c-Jun protein. Therefore, we hypothesize that increased truncation of E-cadherin protein might be responsible for upregulation of c-Jun protein in oral cancer. As we have observed no change in c-Jun mRNA, we hypothesize that an increase in c-Jun protein observed in present study might be due to IRES mediated translation. Moreover, truncated E-cadherin protein showed significant positive correlation with plasma pro MMP-2, plasma active MMP-2, plasma active MMP-9, plasma total MMP-2 and activation ratio MMP-2. Hence, overall results suggest that increase expression of MMPs causes loss of cell-cell adhesion by increased truncation of E-cadherin protein. The loss of E-cadherin is subsequently responsible for increased c-Jun protein in oral cancer.

In conclusion, MMPs plays an important role in disruption of cell-cell adhesion by loss of E-cadherin protein, which subsequently is responsible for increase in c-Jun protein in oral cancer. c-Jun may serve as an predictive marker for evaluating prognosis of oral cancer patients and may serve as an important therapeutic drug target for future interventions. Moreover, significant changes in MMPs observed in patients with OPC highlights the role of MMPs in early progression of oral cancer.

\section{Acknowledgment}

The authors are thankful to The Gujarat Cancer Society, Ahmedabad, Gujarat, India for funding.

\section{Conflicts of Interest}

None 
Bhairavi N. Vajaria, Kinjal R. Patel, Rasheedunnisa Begum, Franky D. Shah, Jayendra B. Patel, Geeta M. Joshi, and Prabhudas S. Patel / American Journal of Oral medicine (2017) Vol. 3 No. 1 pp. 1-24

\section{References}

Al-Rawi, N. H., Al-Kassam, T. K., \& Majeed, A. H. (2014). Expression of matrix metalloproteinase-2 and 9 with their inhibitors, tissue inhibitors of metalloproteinase- 1 and 2 in oral lichen planus. Journal of Orofacial Sciences, 6(1), 25. https://doi.org/10.4103/0975-8844.132576

Blau, L., Knirsh, R., Ben-Dror, I., Oren, S., Kuphal, S., Hau, P., ... \& Vardimon, L. (2012). Aberrant expression of c-Jun in glioblastoma by internal ribosome entry site (IRES)-mediated translational activation. Proceedings of the National Academy of Sciences, 109(42), E2875-E2884. https://doi.org/10.1073/pnas.1203659109

Chatzistamou, I., Schally, A. V., Sun, B., Armatis, P., \& Szepeshazi, K. (2000). Inhibition of growth of OV-1063 human epithelial ovarian cancers and c-jun and c-fos oncogene expression by bombesin antagonists. British journal of cancer, 83(7), 906. https://doi.org/10.1054/bjoc.2000.1374

De Sousa, S. O. M., Mesquita, R. A., Pinto, D. S., \& Gutkind, S. (2002). Immunolocalization of c-Fos and c-Jun in human oral mucosa and in oral squamous cell carcinoma. Journal of oral pathology \& medicine, 31(2), 78-81. https://doi.org/10.1046/j.0904-2512.2001.10012.x

Dorudi, S., Hanby, A. M., Poulsom, R., Northover, J., \& Hart, I. R. (1995). Level of expression of E-cadherin mRNA in colorectal cancer correlates with clinical outcome. British journal of cancer, 71(3), 614. https://doi.org/10.1038/bjc.1995.119

Fan, H. X., Li, H. X., Chen, D., Gao, Z. X., \& Zheng, J. H. (2012). Changes in the expression of MMP2, MMP9, and ColIV in stromal cells in oral squamous tongue cell carcinoma: relationships and prognostic implications. Journal of Experimental \& Clinical Cancer Research, 31(1):90. https://doi.org/10.1186/1756-9966-31-90

Ferlay, J., Soerjomataram, J., Ervik, M., Dikshit, R., Eser, S., Mathers, C., Rebelo, M., Parkin, D.M., Forman, D., Bray, F. (2012) Globocan 2012 v1.0, Cancer incidence and mortality worldwide: IARC Cancer Data Base No. 11.

Freisch SM (1997). The epithelial cell default-phenotype hypothesis and its implications for cancer. Bioessays 1997; 19: 705-709. https://doi.org/10.1002/bies.950190811

Freitas Silva, B. S., Yamamoto-Silva, F. P., Pontes, H. A. R., Júnior, P., \& dos Santos, D. (2014). E-cadherin downregulation and Twist overexpression since early stages of oral carcinogenesis. Journal of Oral Pathology \& Medicine, 43(2), 125-131. https://doi.org/10.1111/jop.12096

Garinis, G. A., Manolis, E. N., Spanakis, N. E., Patrinos, G. P., Peros, G., \& Menounos, P. G. (2003). High frequency of concomitant nm23-H1 and E-cadherin transcriptional inactivation in primary noninheriting colorectal carcinomas. Journal of molecular medicine, 81(4), 256-263. https://doi.org/10.1007/s00109-003-0420-4

Gialeli, C., Theocharis, A. D., \& Karamanos, N. K. (2011). Roles of matrix metalloproteinases in cancer progression and their pharmacological targeting. FEBS journal, 278(1), 16-27. https://doi.org/10.1111/i.1742-4658.2010.07919.x

González-Moles, M. A., Bravo, M., Ruiz-Avila, I., Gil-Montoya, J. A., Acebal, F., \& Esteban, F. (2013). E-cadherin in non-tumor epithelium adjacent to oral cancer as risk marker for the development of multiple tumors. British Journal of Oral and Maxillofacial Surgery, 51(2), 157-163. https://doi.org/10.1016/j.bjoms.2012.05.001

Goyal, A., Martin, T. A., Mansel, R. E., \& Jiang, W. G. (2008). Real time PCR analyses of expression of Ecadherin, alpha-, beta-and gamma-catenin in human breast cancer for predicting clinical outcome. World 
Bhairavi N. Vajaria, Kinjal R. Patel, Rasheedunnisa Begum, Franky D. Shah, Jayendra B. Patel, Geeta M. Joshi, and Prabhudas S. Patel / American Journal of Oral medicine (2017) Vol. 3 No. 1 pp. 1-24

journal of surgical oncology, 6(1), 1-6. https://doi.org/10.1186/1477-7819-6-56

Greene, F.I., Page, D.l., Fleming, I.D. (2002) American joint committee on cancer (AJCC). Head and neck sites. In: Cancer staging manual. 6th ed. Philadelphia, PA: JB Lippincott 17-87. https://doi.org/10.1007/978-1-4757-3656-4

Kaur, G., Carnelio, S., Rao, N., \& Rao, L. (2009). Expression of E-cadherin in primary oral squamous cell carcinoma and metastatic lymph nodes: an immunohistochemical study. Indian Journal of Dental Research, 20(1), 71. https://doi.org/10.4103/0970-9290.49075

Kaur, J., Sawhney, M., DattaGupta, S., Shukla, N. K., Srivastava, A., Walfish, P. G., \& Ralhan, R. (2013). Clinical significance of altered expression of $\beta$-catenin and E-cadherin in oral dysplasia and cancer: potential link with ALCAM expression. PLoS One, 8(6), e67361. https://doi.org/10.1371/journal.pone.0067361

Khan, Z. U. (2012). An Overview of Oral Cancer in Indian Subcontinent and Recommendations to Decrease its Incidence. Webmed Central Cancer 3(8), WMC003626.

Knirsh, R., Ben-Dror, I., Spangler, B., Matthews, G. D., Kuphal, S., Bosserhoff, A. K., \& Vardimon, L. (2009). Loss of E-cadherin-mediated cell-cell contacts activates a novel mechanism for up-regulation of the protooncogene c-Jun. Molecular biology of the cell, 20(7), 2121-2129. https://doi.org/10.1091/mbc.E08-12-1196

Kowalski, P. J., Rubin, M. A., Kleer, C. G. (2003). E-cadherin expression in primary carcinomas of the breast and its distant metastases. Breast Cancer Research, 5, R217-22. https://doi.org/10.1186/bcr651

Kuo, R. C., Lin, C. Y., \& Kuo, M. Y. P. (2006). Prognostic role of c-Jun activation in patients with areca quid chewing-related oral squamous cell carcinomas in Taiwan. Journal of the Formosan Medical Association, 105(3), 229-234. https://doi.org/10.1016/S0929-6646(09)60310-7

Kwon, O., Jeong, S. J., Kim, S. O., He, L., Lee, H. G., Jang, K. L., ... \& Ahn, J. S. (2010). Modulation of E-cadherin expression by K-Ras; involvement of DNA methyltransferase-3b. Carcinogenesis, 31(7), 1194-1201. https://doi.org/10.1093/carcin/bgq071

Lima, J. S., Correa, L., Klingbeil, M. F. G., \& de Sousa, S. C. O. M. (2016). c-Jun, pc-Jun, and p27 are differently expressed in oral leukoplakias in smokers and never-smokers. Oral surgery, oral medicine, oral pathology and oral radiology, 121(1), 73-80. https://doi.org/10.1016/j.0000.2015.09.003

Lorenzo, J. A., Pilbeam, C. C., Kalinowski, J. F., \& Hibbs, M. S. (1992). Production of both 92-and 72-kDa gelatinases by bone cells. Matrix, 12(4), 282-290. https://doi.org/10.1016/S0934-8832(11)80080-6

Lowry, O. H., Rosebrough, N. J., Farr, A. L., \& Randall, R. J. (1951). Protein measurement with the Folin phenol reagent. J Biol Chem, 193(1), 265-275.

Luo, S. L., Xie, Y. G., Li, Z., Ma, J. H., \& Xu, X. (2014). E-cadherin expression and prognosis of oral cancer: a meta-analysis. Tumor Biology, 35(6), 5533-5537. https://doi.org/10.1007/s13277-014-1728-0

Mishra, A., Bharti, A. C., Saluja, D., \& Das, B. C. (2010). Transactivation and expression patterns of Jun and Fos/AP-1 super-family proteins in human oral cancer. International Journal of Cancer, 126(4), 819-829.

More, Y., D'cruz, A. (2013) Oral cancer: Review of current management strategies. Nat Med J India 26, 152158.

Navrocki-Raby, B., Gilles, C., Polette, M., Bruyneel, E., Laronze, J. Y., Bonet, N. et al. (2003). Upregulation of MMPs by soluble E-cadherin in human lung tumor cells. International Journal of Cancer, 105(6):790-795. https://doi.org/10.1002/ijc.11168 
Bhairavi N. Vajaria, Kinjal R. Patel, Rasheedunnisa Begum, Franky D. Shah, Jayendra B. Patel, Geeta M. Joshi, and Prabhudas S. Patel / American Journal of Oral medicine (2017) Vol. 3 No. 1 pp. 1-24

Polak, P., Oren, A., Ben-Dror, I., Steinberg, D., Sapoznik, S., Arditi-Duvdevany, A., \& Vardimon, L. (2006). The cytoskeletal network controls c-Jun translation in a UTR-dependent manner. Oncogene, 25(5), 665-676. https://doi.org/10.1038/sj.onc.1209114

Popov, Z., de Medina, S. G. D., Lefrere-Belda, M. A., Hoznek, A., Bastuji-Garin, S., Abbou, C. C., ... \& Chopin, D. K. (2000). Low E-cadherin expression in bladder cancer at the transcriptional and protein level provides prognostic information. British journal of cancer, 83(2), 209.

Rao, S. V. K., Mejia, G., Roberts-Thomson, K., \& Logan, R. (2013). Epidemiology of oral cancer in Asia in the past decade-an update (2000-2012). Asian Pacific Journal of Cancer Prevention, 14(10), 5567-5577. https://doi.org/10.7314/APJCP.2013.14.10.5567

Rashid, M. G., Sanda, M. G., Vallorosi, C. J., Rios-Doria, J., Rubin, M. A., \& Day, M. L. (2001). Posttranslational truncation and inactivation of human E-cadherin distinguishes prostate cancer from matched normal prostate. Cancer research, 61(2), 489-492.

Roy, R., Yang, J., \& Moses, M. A. (2009). Matrix metalloproteinases as novel biomarker s and potential therapeutic targets in human cancer. Journal of Clinical Oncology, 27(31), 5287-5297. https://doi.org/10.1200/JC0.2009.23.5556

Shah, M. H., Sainger, R. N., Telang, S. D., Pancholi, G. H., Shukla, S. N., \& Patel, P. S. (2009). E-Cadherin truncation and sialyl Lewis-X overexpression in oral squamous cell carcinoma and oral precancerous conditions. Neoplasma, 56(1), 40-47. https://doi.org/10.4149/neo 20090140

Shrestha, B., Subedi, S., Bayracharya, D., \& Radhakrisnan, R. (2014). Immunohistochemical expression of MMP-2 in an experimental progression model of oral cancer. Journal of Chitwan Medical College, 4(2), 38. https://doi.org/10.3126/icmc.v4i2.10852

Singh, R. D., Haridas, N., Patel, J. B., Shah, F. D., Shukla, S. N., Shah, P. M., \& Patel, P. S. (2010). Matrix metalloproteinases and their inhibitors: correlation with invasion and metastasis in oral cancer. Indian Journal of Clinical Biochemistry, 25(3), 250-259. https://doi.org/10.1007/s12291-010-0060-8

Singh, R. D., Nilayangode, H., Patel, J. B., Shah, F. D., Shukla, S. N., Shah, P. M., \& Patel, P. S. (2010). Combined evaluation of matrix metalloproteinases and their inhibitors has better clinical utility in oral cancer. The International journal of biological markers, 26(1), 27-36. https://doi.org/10.5301//BM.2011.6359

Spangler, B., Vardimon, L., Bosserhoff, A. K., \& Kuphal, S. (2011). Post-transcriptional regulation controlled by E-cadherin is important for c-Jun activity in melanoma. Pigment cell \& melanoma research, 24(1), 148-164. https://doi.org/10.1111/i.1755-148X.2010.00787.x

Specenier, P., Brouwer, A. (2015) Matrix metalloproteinase in head and neck cancer. World J Surg Med Radiat Oncol 4:18-27.

Sridevi, U., Jain, A., Nagalaxmi, V., Kumar, U. V., \& Goyal, S. (2015). Expression of E-cadherin in normal oral mucosa, in oral precancerous lesions and in oral carcinomas. European journal of dentistry, 9(3), 364. https://doi.org/10.4103/1305-7456.163238

Tao, D. T., Gao, Z. L., Zhou, J. P., He, L. P., Shi, L. X., Fang, Y., ... \& Deng, C. (2014). Zinc dependent endopeptidases of matrix metalloproteinases- 9 expression is associated with tumor metastases of oral squamous cell carcinoma in Chinese population: a meta-analysis. International journal of clinical and experimental medicine, 7(6), 1531.

Tsuji, T., Ibaragi, S., Hu, G. F. (2009). Epithelial mesenchymal transition and cell cooperativity in metastasis. Cancer Research, 69, 7135-7139. https://doi.org/10.1158/0008-5472.CAN-09-1618

Vered, M., Allon, I., Buchner, A., \& Dayan, D. (2012). E-cadherin in oral SCC: an analysis of the confusing 
Bhairavi N. Vajaria, Kinjal R. Patel, Rasheedunnisa Begum, Franky D. Shah, Jayendra B. Patel, Geeta M. Joshi, and Prabhudas S. Patel / American Journal of Oral medicine (2017) Vol. 3 No. 1 pp. 1-24

literature and new insights related to its immunohistochemical expression. Histology and histopathology, 27(1), 141.

Vihenen P., Kahari, V.M., (2002). Matrix metalloproteinases in cancer: prognostic markers and therapeutic targets. International Journal of Cancer, 99(2), 157-166. https://doi.org/10.1002/ijc.10329

Yadav, L., Puri, N., Rastogi, V., Satpute, P., Ahmad, R., \& Kaur, G. (2013). Matrix metalloproteinases and cancer-roles in threat and therapy. Asian Pacific journal of cancer prevention: APJCP, 15(3), 1085-1091. https://doi.org/10.7314/APICP.2014.15.3.1085

Yao, D. B., Dai, C., Peng, S. (2011). Mechanism of mesenchymal epithelial transition and its relationship with metastatic tumor formation. Molecular Cancer Research, 9(12), 1608-1620. https://doi.org/10.1158/1541-7786.MCR-10-0568

Zhang, C. Y., Mao, L., Li, L., Tian, Z., Zhou, X. J., Zhang, Z. Y., \& Li, J. (2007). Promoter methylation as a common mechanism for inactivating E-cadherin in human salivary gland adenoid cystic carcinoma. Cancer, 110(1), 87-95. https://doi.org/10.1002/cncr.22758

Zhang, C., Man, D. P., Ma, S. M., Cao, S. W., \& Li, D. W. (2012). [Expressions and significances of CD147, OPN and MMP-2 in oral squamous cell carcinoma]. Sichuan da xue xue bao. Yi xue ban= Journal of Sichuan University. Medical science edition, 43(5), 683-686.

Zheng, W. Y., Zhang, D. T., Yang, S. Y., \& Li, H. (2015). Elevated matrix metalloproteinase-9 expression correlates with advanced stages of oral cancer and is linked to poor clinical outcomes. Journal of Oral and Maxillofacial Surgery, 73(12), 2334-2342. https://doi.org/10.1016/i.joms.2015.05.041

Zhou, J., Tao, D., Xu, Q., Gao, Z., \& Tang, D. (2014). Expression of E-cadherin and vimentin in oral squamous cell carcinoma. International journal of clinical and experimental pathology, 8(3), 3150-3154. 